The Catholic University of America, Columbus School of Law

CUA Law Scholarship Repository

2013

\title{
God and the Profits: Is there Religious Liberty for Money-Makers?
}

Mark L. Rienzi

The Catholic University of America, Columbus School of Law

Follow this and additional works at: https://scholarship.law.edu/scholar

Part of the Constitutional Law Commons, First Amendment Commons, and the Religion Law Commons

Recommended Citation

Mark L. Rienzi, God and the Profits: Is there Religious Liberty for Money-Makers?, 21 GEO. MASON L. REV. 59 (2013).

This Article is brought to you for free and open access by the Faculty Scholarship at CUA Law Scholarship Repository. It has been accepted for inclusion in Scholarly Articles and Other Contributions by an authorized administrator of CUA Law Scholarship Repository. For more information, please contact edinger@law.edu. 


\title{
GOD AND THE PROFITS: \\ IS THERE RELIGIOUS LIBERTY FOR MONEYMAKERS?
}

\author{
Mark L. Rienzi*
}

No one can serve two masters. Either he will hate the one and love the other, or he will be devoted to the one and despise the other. You cannot serve both God and Money.

— The Gospel According to Matthew, circa 80 A.D.'

Hercules Industries's overriding purpose is to make money .... [T] that Hercules Industries is anything other than a for-profit, secular employer. . . . By definition, a secular employer does not engage in any "exercise of religion."

- United States Department of Justice, June 8, 2012. ${ }^{2}$

\section{INTRODUCTION}

Religion and business have been closely intertwined throughout the American experience. The original corporate charter for the Virginia Company in 1606 addressed both commercial matters like the granting of mining rights, ${ }^{3}$ and religious matters like the propagation of the Christian faith. ${ }^{4} \mathrm{Pu}-$ ritan merchants in New England started each new ledger with the inscription:

* Associate Professor, The Catholic University of Amcrica, Columbus School of Law; Senior Counsel, the Becket Fund for Religious Liberty. The Author has represented religious business owners and their businesses asserting religious liberty claims in several cases, including Hobby Lobby Stores, Inc. v. Sebelius, 870 F. Supp. 2d 1278 (W.D. Okla. 2012) (challenge to the HHS contraceptive mandate by craft store chain and its owners), rev'd, No. 12-6294, 2013 U.S. App. LEXIS 13316 (10th Cir. June 27, 2013), and Morr-Fitz, Inc. v. Quinn, 976 N.E.2d 1160 (Ill. App. Ct. 2012) (pharmacy successfully asscrting conscience rights not to scll emergency contraception). Thank you to Mary Ann Glendon, Michael Stokes Paulsen, Robin Wilson, Kevin Walsh, Rick Garnett, Will Haun, Kristin Stitcher, Stephanie Sautter, Jay Kozak, and my colleagues at CUA and the Becket Fund for comments and support. The views expressed herein are mine and not necessarily those of my employers or of those who have been kind enough to help me with this project.

1 Matthew 6:24 (New Int'l Version).

2 Defendants' Memorandum in Support of Their Motion to Dismiss and in Opposition to Plaintiffs' Motion for Preliminary Injunction at 17, Newland v. Sebclius, 881 F. Supp. 2d 1287 (D. Colo. 2012) (No. 1:12-cv-01123-JLK) [hereinafter DOJ Hercules Motion to Dismiss] (internal citations omitted).

3 The First Charter of Virginia; April 10, 1606, THE AVALON PROJECT, http://avalon.law. yale.edu/17th_century/va01 asp (last visited Oct. 2, 2013) (granting the corporation the right "to dig, mine, and search for all Manner of Mines of Gold, Silver, and Copper").

4 Id. (referring to the corporation's "noble ... [w]ork" that would include "propagating of Christian Religion" so as to bring Native Americans to "the true Knowledge and Worship of God"); see also JAMES H. Hutson, RELIGION AND THE FOUNDING OF THE AMERICAN REPUBliC 17 (1998) (noting that Virginia was founded by entreprencurs who also viewed themselves as "militant Protestants"). 
"[I]n the name of God and profit."5 So long as God came first in their lives and businesses, they saw nothing wrong with pursuing financial success. ${ }^{6}$

Over the centuries, the nation's religious diversity has increased. The United States is now home to many different religious traditions and many different religious views on moneymaking. Some groups profess God wants them to be fabulously wealthy, ${ }^{7}$ while others seek God by adopting a life of poverty. ${ }^{8}$ In a religiously pluralistic society, such a diversity of views on religion and moneymaking is hardly surprising.

One result of this religious diversity is that some participants in our market economy attempt to exercise religion and make money at the same time. This juxtaposition of religion and moneymaking raises potentially thorny questions of religious liberty law. Can a for-profit business-which today will often be organized as a corporation - engage in a protected "exercise of religion"? Can government regulation of that profit-making business be understood to impose a burden on the business owner's religion? Or is it the case that, to borrow a phrase from the Gospel of Matthew, one "cannot serve both God and Money"??

These questions are not entirely new. The Supreme Court has previously recognized religious liberty rights for people earning a living, ${ }^{10}$ including some business owners. ${ }^{11}$ And the Court has repeatedly recognized that the corporate form itself is not inherently incompatible with religious exercise, at least in the context of nonprofit corporations. ${ }^{12}$ But these decisions have

5 JOHN STEELE GORDON, AN EMPIRE OF WEALTH: THE EPIC HISTORY OF AMERICAN ECONOMIC POWER 27 (2004).

6 Id. In his biography of Benjamin Franklin, Walter Isaacson explains that Puritans viewed religion and commerce as closcly connected. See WALTER ISAACSON, BEN FRANKLIN: AN AMERICAN LIFE 8-10 (2003) ("But to set up such a sharp dichotomy is to misunderstand the Puritans-and America. For most Puritans, ranging from rich John Winthrop to poor Josiah Franklin, their errand into the wilderness was propelled by considerations of both faith and finance... These Puritans would not have made an either/or distinction between spiritual and secular motives.").

7 See David Van Biema \& Jeff Chu, Does God Want You to Be Rich?, Time (Scpt. 10, 2006), http://www.time.com/time/magazine/article/0,9171,1533448,00.html.

8 P.D. Premasiri, Religious Values and the Mcasurement of Poverty: A Buddhist Perspective 4 (Jan. 1999) (manuscript), available at http://siteresources.worldbank.org/INTPOVERTY/Resources/ WDR/johannesburg/buddhist.pdf.

9 Matthew 6:24 (New Int'l Version).

10 See, e.g., Sherbert v. Verner, 374 U.S. 398, 404 (1963) (concluding that a state government could not force a Seventh Day Adventist "to choose between following the precepts of her religion and forfeiting benefits on the one hand, and abandoning one of the precepts of her religion in order to accept work, on the other hand").

11 See, e.g., Braunfeld v. Brown, 366 U.S. 599, 605 (1961) (recognizing the religious burden imposed on Jewish store owners by a Sunday closing law).

12 See, e.g., Gonzales v. O Centro Espirita Beneficente Uniao do Vegetal, 546 U.S. 418, 439 (2006), (allowing a Ncw Mcxico corporation to prevail on a RFRA claim); Church of Lukumi Babalu Ayc, Inc. v. City of Hialeah (Lukumi), 508 U.S. 520, 525, 547 (1993) (awarding a Florida nonprofit corporation relief under the Frec Exercise Clause). 
not directly addressed the question of claimed religious exercise by for-profit business organizations and their owners. ${ }^{13}$

Recent litigation over the Department of Health and Human Services ("HHS") contraceptive mandate has now placed this issue squarely before the courts. In at least thirty-seven cases filed since the beginning of 2012, businesses and their owners have asserted that they have religious exercise rights while earning profits. ${ }^{14}$ The federal government's position is that federal religious liberty law does not protect for-profit business organizations and the individuals who own and operate those businesses. ${ }^{15}$

The crux of the government's argument is its claim that a for-profit business's "overriding purpose is to make money."16 Making money is a goal the government labels "secular," so that "by definition" profit-making businesses "do[] not engage in any "exercise of religion." "17 Business owners are also unprotected under this view because they "have voluntarily chosen to enter into commerce" by operating a profit-making business as a distinct legal entity. ${ }^{18}$ Any claim that owners experience pressure when the government penalizes their businesses is dismissed as a "type of trickle-down theory" of religious liberty for profit makers which courts should reject out of hand. ${ }^{19}$

13 See generally O Centro Espirita, 546 U.S. 418 ; Lukumi, 508 U.S. 520.

14 See infra Part III.A. The cases concem the recently issued HHS requirement that employers provide coverage for all FDA-approved contraceptive drugs and devices.

15 Private parties and state governments have recently made similar claims that profit makers do not have a right to exercise religious liberty. See, e.g., Stormans, Inc. v. Selecky, 586 F.3d 1109, 1119 (9th Cir. 2009) ("Intervenors argue that Stormans, a for-profit corporation, lacks standing to assert a claim under the Frec Exercisc Clausc."); Reply Brief of Defendants-Appellants, Morr-Fitz, Inc. v. Quinn, 976 N.E.2d 1160 (Ill. App. Ct. 2012) (No. 05-CH-494) ("A State-licensed community pharmacy is a secular entity that, by definition, does not 'exercise' a religion. And the individual plaintiffs' claims fare no better, as the rule imposes a burden ... upon pharmacies, not pharmacists." (citation omitted)). Additionally, several states have recently enacted same-sex marriage laws with conscience protections for nonprofit, but not for-profit, religious objectors. See, e.g., CONN. GEN. STAT. ANN. § 46b-35a (West 2011); D.C. CODE $\S 46-406$ (c)(1) (2012 pocket pt.); N.H. REV. STAT. ANN. § 457:37(II)-(III) (201 1); N.Y. DOM. REL. LAW § 10-b(1) (McKinney 2013 pocket pt.); WASH. REV. CODE ANN. § 26.04.010(2), (4) (West 2012); H.B. 438, 2012 Leg., 430th Sess. (Md. 2012); see also Robin Fretwell Wilson, The Calculus of Accommodation: Contraception, Abortion, Same-Sex Marriage, and Other Clashes Between Religion and the State, 53 B.C. L. REV. 1417, 1442 (2012).

16 DOJ Hercules Motion to Dismiss, supra note 2, at 17.

17 Id. In the Hercules case, the government has emphasized the secular nature of the company's products. Id. at 16 ("Hercules Industries . . is an 'HVAC manufacturer.' The company's pursuits and products are not religious."). The government has pursued the same arguments, however, against forprofit businesses with clearly religious products and pursuits, such as Mardel Christian and Education Stores (a Christian bookstore) and Tyndale House Publishers (a Bible publisher). See, e.g., Defendants' Opposition to Plaintiffs' Motion for Preliminary Injunction at 14, Tyndale House Publishers, Inc. v. Sebelius, 904 F. Supp. 2 d 106 (D.D.C. 2012) (No. 1:12-CV-1635-RBW). Despite the obvious religious focus of these businesses, the government has argued that their profit-making nature automatically renders them "secular" and therefore incapable of religious exercise. Id. at 15.

18 Defendants' Opposition, supra note 17, at 15.

19 DOJ Hercules Motion to Dismiss, supra note 2, at 34. 
Over the past year, courts in the HHS mandate cases have split on the question of religious liberty for profit-making businesses and their owners, finding it to be an issue of first impression. ${ }^{20}$ The two courts of appeals to decide the issue on the merits have reached opposite conclusions, with one finding the government must respect the religious exercises of a profit-making business, ${ }^{21}$ and another denying such religious exercises can even happen within a profit-making organization. ${ }^{22}$ Other cases were poised to be decided by other circuits in fall 2013.23

As this issue proceeds through the courts, this Article aims to provide a broader foundation for courts, scholars, and litigants thinking about how and whether profit-making businesses and their owners can exercise religion. The analysis will begin with the question whether, as a factual matter, for-profit business organizations and their owners engage in religious activities. In doing so, this Article will consider some examples of religious rules from various faiths concerning profit-making activities, and examples of businesses that appear to operate based on such religious principles.

Next, the Article will examine how our legal system generally treats forprofit businesses and their owners in other contexts. The goal is to test the underlying assumptions of each side's argument. The claim that for-profit business organizations can actually engage in legally protected "religious exercise" would require the law to recognize the organization itself as capable of forming and acting upon a religious belief. ${ }^{24}$ In other contexts, do our laws

20 Compare Korte v. Scbelius, No. 12-3841, 2012 WL 6757353, at *5 (7th Cir. Dec. 28, 2012) (granting preliminary injunction to business owner and business), with Autocam Corp. v. Scbclius, No. 1:12-CV-1096, 2012 WL 6845677, at*12 (W.D. Mich. Dec. 24, 2012) (denying preliminary injunction to business owner and business), aff'd, No. 12-2673, 2013 WL 5182544 (6th Cir. Sept. 17, 2013); see also Ncwland v. Sebclius, 881 F. Supp. 2d 1287, 1296 (D. Colo. 2012) ("These arguments posc difficult questions of first impression.").

21 Hobby Lobby Stores, Inc. v. Sebelius, No. 12-6294, 2013 WL 3216103, at *17 (10th Cir. Junc 27,2013 ) ("No one disputes in this case the sincerity of Hobby Lobby and Mardel's religious belicfs. And because the contraceptive-coverage requirement places substantial pressure on Hobby Lobby and Mardel to violate their sincere religious beliefs, their excrcise of religion is substantially burdencd within the meaning of RFRA.").

22 Conestoga Wood Specialties Corp. v. Sebclius, No. 13-1 144, 2013 WL 3845365, at *5 (3d Cir. July 26, 2013) ("[W]c simply cannot understand how a for-profit, sccular corporation-apart from its owners-can excrcise rcligion.").

23 The Sixth Circuit ruled in September 2013 that a secular, for-profit company was incapable of "religious cxercisc" and therefore not exempt from the HHS Mandatc. See Autocam Corp. v. Scbelius, No. 12-2673, 2013 WL 5182544 (6th Cir. Scpt. 17, 2013). See also Korte v. U.S. Dep't of Health \& Human Servs., No. $12-3841$ (7th Cir.); O'Brien v. U.S. Dep't of Health \& Human Servs., No. 12-3357 (8th Cir.).

24 See, e.g., Robert K. VISCHER, CONSCIENCE AND THE COMMON GOOD: REClaIMing the SPACE BETWEEN PERSON AND STATE 202-05 (2010) (arguing for conscience rights in for-profit busincsses); Ronald Colombo, The Naked Private Square, 51 HouS. L. REV. (forthcoming Fall 2013) (manuscript at 79), available at http://papers.ssm.com/sol3/papers.cfm?abstract_id=2173801 ("It is time to connect the dots, and explicitly recognize the ability of for-profit corporations to invoke the protections of the Free Excrcise Clause."). 
treat for-profit businesses as capable of forming and acting on subjective religious, philosophical, or ethical beliefs? Those opposing religious liberty rights for profit makers build their argument on a categorical distinction between nonprofit and for-profit entities, and a strict separation between business owners and their businesses..$^{25}$ Do we treat the distinction between nonprofits and for-profits as categorical and determinative in other areas of the law? Do we generally treat business owners themselves as completely insulated from penalties imposed on their businesses?

This Article will conduct the analysis across five different contexts: corporate ethical decision making, criminal law, Title VII discrimination law, tax law, and constitutional law. Understanding how the law treats for-profit businesses in these varied contexts will shed light on whether there is something inherent in the nature of operating a for-profit business which precludes religious liberty claims by businesses and their owners.

When this type of broad analysis is conducted, a very strong argument emerges that profit-making businesses and their owners are capable of engaging in protected religious exercise under federal law. For-profit businesses are widely understood as capable of forming subjective intentions for their actions. ${ }^{26}$ The law recognizes this capability in various ways: businesses are allowed to act on ethical principles, are capable of forming mental intent for crimes, and are held liable for racial, sexual, or religious discrimination. The law also acknowledges that for-profit businesses can speak with a particular viewpoint. ${ }^{27}$ There is no basis to view these same entities as incapable of forming and acting upon beliefs about religion. Observable facts confirm that at least some businesses take actions based on religious beliefs. Examples include closing on the Jewish Sabbath, seeking out loans that comply with Islamic law, or urging the public to accept Jesus Christ as Lord and Savior. ${ }^{28}$ These actions are manifestly exercises of religion. ${ }^{29}$

The fact that the organization urging the public to accept Jesus Christ as Lord and Savior also generates profits does not make the evangelization any less an exercise of religion. In fact, the for-profit/nonprofit distinction carries little or no weight in most areas of the law, including constitutional law. ${ }^{30}$ Where the distinction matters at all, it is often just one factor among many.

25

See, e.g., Elizabcth Scpper, Taking Conscience Seriously, 98 VA. L. REv. 1501, 1547 (2012) (arguing that "[w]ithin for-profit businesses, even though moral convictions might come into play, the profit motive (in some cases, an obligation to maximize sharcholder wcalth) must drive decisionmaking").

26 See infra Part III.

27 See infra Part III.

28 See infra Part I.B.

29 See, e.g., Emp't Div., Dep't of Human Res. of Or. v. Smith, 494 U.S. 872, 876-78 (1990) (noting that the free exercise of religion "first and foremost" includes "the right to believe and profess whatever religious doctrine one believes"), superseded by statute, Religious Land Use \& Institutionalized Persons Act of 2000 (RLUIPA), Pub. L. No. 106-274, 114 Stat. 803, as recognized in Sossamon v. Texas, $131 \mathrm{~S}$. Ct. 1651, 1655-56 (2011).

30 See infra Part II.E. 
The distinction does not operate in ways that suggest profit making is categorically incompatible with religious exercise. Moreover, many areas of the law-including corporate criminal law, Title VII, and tax law-operate on the assumption that business owners will be sensitive to pressures imposed on their businesses. There is no reason to believe for-profit businesses behave any differently in the religious liberty context, or that religious business owners will not feel pressure to abandon their religious practices when the government penalizes their businesses.

For these reasons, the government's argument against religious liberty for profit-making businesses and their owners should be rejected. Denying religious liberty in this context would require abandoning longstanding legal principles, breaking with our usual treatment of for-profit businesses and their owners, and ignoring the real-world practice of many religions and businesses. The better course is to protect religious exercise wherever it occurs regardless of the identity, ownership structure, or tax status of the party engaged in the exercise. In truth, this is the only course permitted under the Free Exercise Clause and federal religious freedom laws.

Part I of this Article addresses the factual question whether for-profit businesses and their owners engage in the exercise of religion by looking at examples of actual businesses and religious teachings. Part II explores the law's treatment of for-profit businesses, their owners, and the for-profit/nonprofit distinction in other areas of the law to determine whether there is something about for-profit businesses that is incompatible with religious exercise. In light of Parts I and II, Part III considers the argument from the HHS Mandate cases that for-profit businesses and their owners cannot exercise religion. Part III concludes that both for-profit businesses and their owners can exercise religion and are protected by federal religious liberty laws.

\section{RELIGION AND BUSINESS IN PRACTICE}

This Part examines whether for-profit businesses actually do "exercise" religion, as that concept is generally understood in religious liberty law. The analysis proceeds in three parts. Part I.A addresses the legal understanding of religious exercise as an act or abstention based on a religious belief. Part I.B briefly considers three religious traditions to examine whether they in fact impose religious requirements on believers' profit-making activities. Part I.C. presents three examples of modern for-profit businesses that take actions that seem to qualify as religious exercise under federal law. 


\section{A. What Is a "Religious Exercise" Under Federal Law?}

Both the First Amendment and federal religious liberty laws protect the "exercise" of religion. ${ }^{31}$ The Supreme Court has explained that the free exercise of religion "means, first and foremost, the right to believe and profess whatever religious doctrine one desires." 32 The Free Exercise Clause prohibits the government from compelling affirmation of any particular religious belief, ${ }^{33}$ punishing expression of disfavored religious doctrines, ${ }^{34}$ or giving its power to any side of controversies over religious authority or dogma. ${ }^{35}$

The "exercise of religion," however, is broader than the freedom of belief and profession. The Court has explained that exercising religion often involves "not only belief and profession but the performance of (or abstention from) physical acts" including "proselytizing" or "abstaining from certain foods or certain modes of transportation." 36 The Court has thus upheld as religious "exercise" religiously motivated decisions to abstain from working on the Sabbath, ${ }^{37}$ to keep one's children out of public schools after a certain age, ${ }^{38}$ and to refrain from manufacturing items that other people may later use in war. ${ }^{39}$ The exercise of religion is not limited to actions or abstentions required by a person's religion, but rather includes actions and abstentions motivated by religion. ${ }^{40}$ Federal statutory law makes clear "religious

31 U.S. ConST. amend. I; Religious Frcedom Restoration Act, 42 U.S.C. $\$ 2000 \mathrm{cc}(a)(1)$ (2006) (imposing a compelling interest test when government imposes a "substantial burden" on religious exercisc); Title V1I, 42 U.S.C. $\$ 2000$ e (2006) (barring employcrs from discriminating against an employee based on his or her religious practices or beliefs).

32 Smith, 494 U.S. at 876-78.

33 See, e.g., Torcaso v. Watkins, 367 U.S. 488, 495 (1961).

34 See, e.g., United States v. Ballard, 322 U.S. 78, 86-88 (1944).

35 See, e.g., Presbyterian Church in the U.S. v. Mary Elizabcth Bluc Hull Mcm'l Presbyterian Church, 393 U.S. 440, 445 (1969)

36 Smith, 494 U.S. at $877-78$.

37 Sherbert v. Verner, 374 U.S. 398, 410 (1963).

38 Wisconsin v. Yoder, 406 U.S. 205, 234 (1972)

39 Thomas v. Revicw Bd. of the Ind. Emp't Scc. Div., 450 U.S. 707, 720 (1981).

40 See, e.g., Smith, 494 U.S. at 877 ("acts or abstentions . . . engaged in for religious reasons, or . . becausc of the religious belicf that they display"); $i d$. at 881 ("religiously motivated action"); $i d$. at 886 ("Nor is it possible to ... requir[c] a 'compelling state interest' only when the conduct prohibited is central to the individual's religion."). Other decisions by the Court confirm that religious cxercise extends to rcligiously motivated conduct. See, e.g., Yoder, 406 U.S. at 215 ("[T]o have the protection of the Religion Clauses, the claims must be rooted in religious bclief."); Sherbert, 374 U.S. at 404 (condemning a state ruling that forced a Seventh Day Evangelist to choose between "following the precepts of her religion and forfeiting benefits"); Braunfeld v. Brown, 366 U.S. 599, 603 (1961) ("action . . in accord with onc's religious convictions"); Cleveland v. United States, 329 U.S. 14, 20 (1946) (noting that an act "motivated by a religious belief' is religious exercise). These decisions are discussed in a letter from the Congressional Research Service submitted during congressional considcration of RFRA. Douglas Laycock \& Oliver S. Thomas, Interpreting the Religious Freedom Restoration Act, 73 TEx. L. REV. 209, 230-36 (1994) (citing Letter from the Am. Law Div. of the Cong. Research Serv. to the Hon. Stephen J. Solarz (Junc 11, 
exercise" is not limited to actions compelled by religion. Rather, "religious exercise" extends to "any exercise of religion, whether or not compelled by, or central to, a system of religious belief." 41

Thus the key to determining whether a particular action is a religious exercise is determining whether religious belief motivates the act. ${ }^{42}$ If the conduct or abstention occurs because of the actor's religious beliefs, it is a religious exercise ${ }^{43}$ If the action is not based on religious beliefs, it is not a religious exercise. ${ }^{44}$

\section{B. Religious Teachings on Religious Exercise, Profit Making, and Corporations}

In order for a profit-making business and its owner to plausibly assert they are engaged in religious exercise, they must first show that their religious beliefs have something to say about the conduct of business. If the owner's religion imposes no requirements on business conduct, a claim of religious exercise in that sphere becomes significantly less likely. ${ }^{45}$

The United States is home to a wide variety of different faiths. ${ }^{46}$ While it would be impossible to catalogue the full range of views on religion and moneymaking across the American religious spectrum - or even within any particular religious tradition - this Section will briefly examine some teachings on the subject from Judaism, Christianity, and Islam. The goal here is not to give a comprehensive analysis of the faiths described. The goal is simply to examine whether these traditions have teachings that impose requirements on their adherents' moneymaking activities, such that claims of religious liberty in the profit-making context are plausible.

1992), reprinted in Religious Freedom Restoration Act of 1991: Hearing on H.R. 2797 Before the Subcomm. on Civil and Constitutional Rights of the H. Comm. on the Judiciary, 102d Cong. 131-33 (1992)) (discussing meaning of religious exercisc under the Free Excrcise Clause and RFRA).

4142 U.S.C. \& $2000 \mathrm{cc}-5(7)$ (A) (2006) (emphasis added). Similarly, Title VII defines "religion" to "include[] all aspects of religious observance and practice, as well as belief." $/ d$. $\S 2000 \mathrm{e}(\mathrm{j})$.

42 Yoder, 406 U.S. at 215 ("A way of life, however virtuous and admirable, may not be interposed as a barricr to reasonable statc regulation of education if it is based on purcly secular considerations; to have the protection of the Religion Clauses, the claims must be rooted in religious belicf.").

43 See Laycock \& Thomas, supra notc 40, at 232 (noting that RFRA's "legislative history is relatively clear" that both "supporters and opponents agreed that the bill would protect conduct that was religiously "motivated").

44 Yoder, 406 U.S. at 215.

45 See Thomas v. Review Bd. of the Ind. Emp't Sec. Div., 450 U.S.707, 716-17 (1981) (quoting Sherbert, 374 U.S. at 404).

46 See The Pew Forum on Religion \& Public life, U.S. Religious Landscape Survey 10 (2008) [hereinafter PEW FORUM], available at http://religions.pewforum.org/pdf/report-religious-landscape-study-full.pdf ("The Landscape Survey details the great diversity of religious affiliation in the U.S. at the beginning of the 21 st century. The adult population can be usefully grouped into more than a dozen major religious traditions that, in turn, can be divided into hundreds of distinct religious groups."). 
While the religious teachings below differ in many respects, important similarities emerge. First, each faith imposes religious obligations on the conduct of business. Second, each religion rejects the notion of separation whereby a business owner is not morally responsible for the actions of the business. Third, each prohibits businesses from providing harmful products or services that others would use to engage in harmful conduct.

\section{Judaism}

In the Old Testament, financial success at times appears to be a manifestation of divine favor, a reward for those who faithfully follow God's will. ${ }^{47}$ Judaism's founding thus reflects a connection between religion and wealth, as God made Abraham, Isaac, Jacob, and Solomon wealthy, at least in part because they obeyed God..$^{48}$

Judaism views earning a living as a necessary aspect of the human experience. ${ }^{49}$ The Jewish faith dictates that wealth, as a blessing from God, must be earned and used in accordance with religious laws. ${ }^{50}$ Therefore, Jewish businesses must be conducted with honesty and integrity. ${ }^{51}$ Some Jewish authorities believe this means that Jewish businesses must avoid providing materials that are harmful to human health, such as tobacco. ${ }^{52}$ Additionally, Jewish law prohibits working, as well as causing others to work, during the Sabbath..$^{53}$ Thus, a religiously observant Jew must close his business from Friday at sundown until Saturday at sundown. The devout Jew may not circumvent Jewish law by hiring non-Jews to work these hours. ${ }^{54}$ Devout Jews view following these religious requirements while engaging in profit-making activities as critically important. ${ }^{55}$ The Talmud, a sacred Jewish text, "suggests that

47 Ronald M. Green, Guiding Principles of Jewish Business Ethics, 7 BUS. ETHICs Q. 21 , 23 (1997); see also Genesis 24:35 (Ncw Rev. Standard Version) ("The Lord has greatly blesscd [Abraham], and he has become wealthy ....").

48 Meir Tamari, The Challenge of Wealth: Jewish Business Ethics, 7 Bus. ETHICs Q. 45,48 (1997).

49 Green, supra note 47 , at 22-23.

50 See Tamari, supra note 48 , at 48 ("Holders of wealth are not possessors but stewards."). In recognition that all wealth stems from God, an old ritual required Jewish farmers to present their first fruits of the scason to God. Id. at 49.

51 Green, supra note 47, at 23.

52 Id. at 29.

53 See The Shabbat Laws, CHABAD.ORG, http://www.chabad.org/library/article_cdo/aid/95907/jewish/The-Shabbat-Laws.htm (last visited Oct. 4, 2013); see also Elliot N. Dorff, Jewish Businesses Open on Shabbat and Yom Tov: A Concurring Opinion, RABBINICAL ASSEMBLY, 64, 65 (1995), http://www.rabbinicalassembly.org/sites/default/filcs/public/halakhah/tcshuvot/19912000/dorff_business.pdf.

54 Dorff, supra note 53, at 65 (" [I]t would be forbidden for the Jew to gain from the non-Jew's sales on those days.").

55 Id. at 64 
the first question asked in the world to come is-'have you been honorable in business?"'s6

In applying religious principles to profit making, Judaism does not distinguish between the business owner's actions and the actions of the business itself. ${ }^{57}$ Rather, Jewish law emphasizes that the profit-making business corporation is not separate from the individual shareholder or owner. ${ }^{58}$ Judaism rejects the notion of "separation of identity" on religious matters, because such separation "creates moral problems since the same person who in his private life would not think of stealing or robbing or breaking the law sees nothing wrong with doing exactly those things in his role as a director or an official of a corporation." 59

In similar fashion, Judaism prohibits even Jewish consumers from facilitating a business owner's violation of Jewish law. ${ }^{60}$ For this reason, Jews are instructed not to purchase bread from Jewish-owned businesses immediately after Passover. The Jewish business owner should not possess grains during Passover, and the Jewish customer is forbidden from rewarding the Jewish business's violation of that law. ${ }^{61}$ The corporate form does not insulate the Jewish business owner from the conduct of the business as a religious matter, nor does it insulate the Jew as a customer. Just as religious requirements prohibit the Jewish customer from purchasing bread from an individual Jewish storeowner, she also cannot purchase from a large corporate store owned by Jewish shareholders. ${ }^{62}$

56 Moses L. Pava, Developing a Religiously Grounded Business Ethics: A Jewish Perspective, 8 Bus. ETHICS Q. 65, 65 (1998) (citing Shabbat 31 a).

57 Id. at 80 .

58 Id.

59 Business Ethics: The Role of Wealth, JEwISH VIRTUAL, LIBRARY, http://www.jewishvirtuallibrary.org/jsourcc/judaica/cjud_0002_0004_0_03774.html (last visited Oct. 4, 2013) ("Judaism . . . cannot accept the separation between the corporation and the individual when it comes to abrogate the responsibilitics of the latter as seen in Jewish business law. ... Jews are not allowed to own leavencd bread during Passover, so a corporation which has a majority of Jewish shareholders would likewise be forbidden from posscssing such leavencd bread. In the same way, the vicw that since the corporation is not a human being, the biblical injunction against interest does not apply to loans between two corporations or between an individual and a corporation has been rejected by most rabbinic authoritics. So, a corporation whose shareholders are Jcwish would suffer the same restriction on lending moncy at interest as do individual Jews. This means that the limitations on business activitics imposed by Jewish moral teachings and rabbinic law, and the social obligations flowing from the possession of wealth, which apply to the individual, arc binding on the corporation as well." (citation omitted)).

60 See Chometz After Pesach, Young ISRAEl Shomrai EMUNAH of Greater WaSh., http://wp.yisc.org/chometz-after-pesach/ (last visited Oct. 4, 2013).

61 See id. ("All Jews are prohibited from bencfitting from chametz owned by another Jew over Pesach. . . Onc should not purchase bread or other chametz for 2 wecks after Pesach from a storc owned by Jcws that did not sell their chametz before Pesach or from a store which purchases chametz from Jcwish distributors that did not sell their chametz before Pesach. This currently includes Giant, Safeway, Superfresh and Target." (emphasis omitted)).

62 See id. 
These teachings suggest that at least some members of the Jewish faith do not view profit making as inherently separate from religious exercise. To the contrary, some observant Jews are likely to feel required to follow a host of religious requirements on their profit-making activities. And these requirements apply equally to a Jewish business owner and the Jewish-owned business itself.

\section{Christianity}

Christian scriptures offer a variety of messages about the proper relationship between profit making and religion. In one part of Matthew's Gospel, for example, Jesus tells the parable of the talents in which a wealthy man leaves three servants in charge of varying sums of money. ${ }^{63}$ Two of the servants "put his money to work" and doubled their sums. ${ }^{64}$ The third "went off, dug a hole in the ground and hid his master's money." 65 When the master returned, the two profit-making servants were celebrated, while the third was cast out "into the darkness, where there [was] weeping and gnashing of teeth." $" 66$

Other parts of the same Gospel, however, indicate a much less favorable view of profit seeking. For example, Jesus expels people who are "buying and selling" from the temple and warns them not to make the temple a "den of robbers." 67 Jesus also preaches that it is not possible to "serve both God and Money," 68 that it is exceedingly hard for a rich person to enter heaven, ${ }^{69}$ and that his followers should sell off all their possessions and give the money to the poor. ${ }^{70}$

As might be expected, these very different statements in the Gospels give rise to a variety of approaches to religion and profit making among modern Christian groups. Christian approaches to the issue run the gamut. Some preach that God wants to show his people how to be wealthy. ${ }^{71}$ There are also

63 Matthew 25:14 to:30 (New Rev. Standard Version).

64 Matthew 25:16 to:17 (New Int'l Version).

65 Id. at $25: 14$ to $: 18$.

66 Id. at $25: 21$ to $: 30$.

67 Id. at $21: 12$ to $: 13$ (internal quotation marks omitted).

68 Id. at $6: 24$

69 Id. at $19: 23$ to $: 24$.

70 Matthew 19:21.

71 Prosperity Theology is onc example of this belief. See JOEL OSTEEN, YOUR BEST LIFE NOw: 7 Steps to Living at Your Full Potential 3-4 (2004); Oral Roberts, God's Formula for SuCCESS AND PROSPERITY 12-13 (Abundant Life Publ'n rev. ed. 1966) (1955); God's Promise OF WEALTH, http://godswcalth.webs.com ("Welcome to God's Promise of Wealth. . . [T] [he underlying principle for this site is at Deuteronomy 8-18. His words are very casy to understand and lay the foundation for us amassing wealth. He tells us, 'But remember the Lord your God, for it is He who gives you the ability to produce wealth.'") (last visited Oct. 4, 2013). 
Christian religious orders that take a vow of poverty, believing that forsaking worldly wealth makes it easier for them to commune with God. ${ }^{72}$ Intense discussion of the proper relationship between Christianity and profit making remains ongoing. ${ }^{73}$

One group with a particularly well-developed set of teachings on this issue is the Catholic Church, the largest Christian denomination in the United States. ${ }^{74}$ Catholic teaching makes clear that business and profit making are not viewed as inconsistent with religious exercise. ${ }^{75}$ Rather, " $[t]$ he vocation of the businessperson is a genuine human and Christian calling." 76 When properly managed, profit-making businesses "actively enhance the dignity of employees and the development of virtues such as solidarity, practical wisdom, justice, discipline, and many others." $"$ "In this regard, Christian business leaders are urged to pursue their vocation, "motivated by much more than financial success." $" 78$

The Church views the business leader's development of the corporate business organization as vocational: "Business leaders have a special role to

72 See, e.g., Vows, SiSTERS OF CHARITY OF OUR LADY MOTHER OF THE CHURCH, http://sistersofcharity.com/vows (last visited Oct. 4, 2013) ("By her vow of poverty, following in the footsteps of Christ, a Sister professes to live a life that is poor in fact and in spirit. It is a life of labor lived in moderation and simplicity, rejecting the lure of earthly riches, a life that proclaims to the world that God is the one thing necessary.").

73 For example, Rick Warren, a popular evangelical pastor, presented a serics of scrmons on the subject titled "Doing Business With God" in late 2012. See Rick Warren, Doing Business with God, SADDLEBACK RESOURCES, http://www.saddlebackresources.com/024300_Doing-Business-With-GodC3202.aspx (last visited Oct. 4, 2013); see also RANDY ALCORN, MONEY, POSSESSIONS AND ETERNITY 86 (rev. ed. 2003) (encouraging Christians to "say no to prosperity theology, obcy Christ, and share your abundance with others"); LARRY BURKETT, BUSINESS BY THE BOOK: THE COMPLETE GUIDE OF BIBLICAL PRINCIPLES FOR THE WORKPLACE 4 (1998) (promoting a business philosophy that is "more concerncd with eternity than with profits"); TIMOTHY KELLER \& KATHERINE LEARY ALSDORF, EVERY GOOD ENDEAVOR: CONNECTING YOUR WORK TO GOD'S WORK 19 (2012) ("[O]ur work can be a calling only if it is reimagined as a mission of service to something beyond mercly our own interests.").

74 See PEW FORUM, supra notc 46, at 12-13.

75 See generally PONTIFICAL COUNCIL FOR JUSTICE \& PEACE, Vocation of the Business LEADER: A REFLECTION (3d cd. 2012) [hercinaftcr VOCATION OF THE BUSINESS LEADER], available at http://www.sthomas.edu/cathstudies/cst/VocationBusinessLead/VocationTurksonRemar/VocationBk3rdEdition.pdf (summarizing Catholic teaching on religion and business). Pope Benedict XVI also addressed the relationship between business and religion in his 2009 papal encyclical "Charity in Truth." Under the heading of "The Development of People-Rights and Duties-The Environment," the Pope explained that the "Church's social teaching is quitc clear on the subject" that "the economy, in all its branches, constitutes a sector of human activity" and therefore is subject to religious ethical norms. Encyclical Letter, Caritas in Veritate, of the Supreme Pontiff Benedict XVI to the Bishops, Priests and Deacons, Men and Women Religious, the Lay Faithful, and All Pcoplc of Good Will on Integral Human Development in Charity and Truth of 45 (Junc 29, 2009), available at http://www.vatican.va/ holy_father/benedict_xvi/encyclicals/documents/hf_ben-xvi_cnc_20090629_caritas-in-veritate_cn.html.

76 VOCATION OF THE BUSINESS LEADER, supra note 75 , at 5.

77 Id. at 4

78 ld. at 3 
play in the unfolding of creation ... [by] help[ing] to shape organisations that will extend this work into the future." 79 By creating and sustaining corporate entities, business leaders "are participating in the work of the Creator through their stewardship of productive organisations" that the Church views as an "awesome responsibility of their vocation." lic business leaders are to avoid thinking of themselves as morally separate from the actions of their businesses ${ }^{81}$ Church teaching urges business leaders to overcome this divide and "integrate the gifts of the spiritual life" into their business dealings. ${ }^{82}$

The Vatican teaches that principles of justice, rather than mere profit maximization, should guide Catholic business organizations. ${ }^{83}$ Businesses and their leaders are also urged to "find ways to make a just distribution of ... wealth"- not only to shareholders - but also "to employees (following the principle of the right to a just wage), customers (just prices), owners (just returns), suppliers (just prices) and the community (just tax rates)." ${ }^{84}$ Businesses must avoid actions that undermine the common good because "we are all really responsible for all." ${ }^{\prime 5}$ Therefore, "[a]t the very least, a good business

79 Id. at 5.

80 Id. The Church views corporations and companies as "communit[ies] of persons." Id. at 18 ("[T] he purpose of business, [as] Blessed John Paul II stated 'is not simply to make a profit, but is to be found in its very existence as a community of persons who in various ways are endeavouring to satisfy their basic needs, and who form a particular group at the service of the whole of society.' . . When we consider a business organization as a community of persons, it becomes clear that the bonds which hold us in common are not merely legal contracts or mutual self-interests, but commitments to real goods, shared with others to scrve the world." (footnote omitted)).

81 Id. at 6 (stating that "[d]ividing the demands of one's faith from one's work in business is a fundamental crror" and leads to a "divided life" that "is fundamentally disordered, and thus fails to live up to God's call.").

82 VOCATION OF THE BUSINESS LEADER, supra note 75, at 3. See also Warren, supra note 73 (explaining that profits should not be an end in themselves and that Christians should avoid separating their faith from their business dealings).

83 VOCATION OF THE BUSINESS LEADER, supra note 75, at 17 ("While profitability is an indicator of organisational health, it is neither the only one, nor the most important by which business should be judged. Profit is necessary to sustain a business; however, 'once profit becomes the cxclusive focus, if it is produced by improper means and without the common good as its end, it risks destroying prosperity and creating poverty.' Profit is likc food. An organism must eat, but that is not the overriding purpose of its existence. Profit is a good servant, but it makes a poor master." (footnotes omitted)).

$84 \mathrm{Id}$. at 18 ("Just as financial resources are important, so too is stewardship of the environment, both physical and cultural. ... As collaborators with God in the unfolding of creation, ... we have a duty to respect and not to attack the world around us.").

85 Id. at 11 (quoting Encyclical Letter, Sollicitudo Rei Socialis, from Pope John Paul II to the Bishops, Priests, Religious Families, Sons and Daughters of the Church, and All People of Good Will for the Twentieth Anniversary of Populorum Progressio of 38 (Dec. 30, 1987), available at http://www.vatican.va/holy_father/john_paul_ii/encyclicals/documents/hf_jp-ii_enc_30121987_sollicitudo-rei-socialis_en.html) (internal quotation marks omitted); see also id. (asserting that "each of us has a duty to avoid actions which impede the flourishing of others"). In explaining how businesses should seck human 
carefully avoids any actions that undermine the local or global common good." 86 This prohibition on harming the common good includes avoiding providing products that can "be detrimental to human well-being as, for example, in the sale of non-therapeutic drugs, pornography, gambling, violent video games, and other harmful products." ${ }^{7} 7$

Thus, as with Judaism, these teachings suggest at least some Christians do not view profit making as inherently separate from religious exercise. To the contrary, at least some Christians presumably feel required to follow a host of religious requirements on their profit-making activities and understand those requirements to extend to the corporations they own and operate.

\section{Islam}

Like Judaism and Christianity, Islam imposes religious requirements on business owners and their for-profit businesses. These requirements extend to issues concerning pricing and profits, general treatment of customers, sales of forbidden goods, and borrowing or lending money at interest.

Islam views business as having not merely economic functions, but also social and religious functions. ${ }^{88}$ While pursuit of profits is permitted and encouraged ${ }^{89}$ profitability must always be balanced with other social and religious needs, such as providing efficient and courteous service. ${ }^{90}$ Profitability

flourishing, the Church teaches as a "foundational ethical principle for business" that "cach person, regardless of age, condition, or ability, is an image of God and so endowed with an irreducible dignity or value. Each person is an end in him or herself, never merely an instrument to be valued only for its utilitya who, not a what; a someone, not a something. This dignity is possessed simply by virtue of being human. It is never an achievement, nor a gift from any human authority; nor can it be lost, forfeited, or justly taken away." Id. (footnote omitted).

$86 \mathrm{Id}$. at 12 . The obligation to avoid having any involvement at all in someone else's sinful acts has long been the subject of Protestant Christian tcachings as well. See, e.g., JoHn CaLvin, CoMmENTARIES ON THE EPistle of Paul to the Galatians and EPHeSians 262 (William Pringle trans., 2009), available at http://www.ccel.org/ccel/calvin/comment3/comm_vol41/htm/iv.vi.iii.htm ("It is not cnough that we do not, of our own accord, undertake anything wicked. We must beware of joining or assisting those who do wrong. In short, we must abstain from giving any consent, or advice, or approbation, or assistance; for in all these ways we have fellowship.").

87 VOCATION OF THE BUSINESS LEADER, supra note 75, at 14.

88 NIK MOHAMED AFFANDI BIN NIK YUSOFF, ISLAM \& BUSINESS 85 (Ismail Noor cd., 2002).

89 Zubair Hasan, Theory of Profit: The Islamic Viewpoint, 1 J. RES. ISLAMIC ECON. 3, 8 (1983) ("Islam exhorts the believers to excel in this life no less than in the life hereafter. It urges them to engage in almost every material pursuit, especially trade and culogizes profit and God's bounty."). The Qur'an cncourages Muslims to generously spend their wealth. See THE MEANING OF THE HOLY QUR'AN 105 (Abdullah Yusuf Ali trans., 9th cd. 1997) (Surah 2:254: "Spend out of (the bountics)/We have provided for you ...." (footnote omitted)); id. at 1697 (Surah 104-Al Humazah: "Woe to the miser who blocks up the channels/Of use and service and dams up his wealth,/As if he could remain in posscssion/For all time! The Fire of Wrath will envelop them/And wither up their hearts and minds, and consume/That largeness of life which is the portion of mankind."); YUSOFF, supra note 88, at 85.

90 YUSOFF, supra note 88 , at 85. 
must also be balanced against providing only beneficial, good-quality, and reasonably priced goods to consumers. ${ }^{91}$ Practiced in this manner, Islamic business "is an essential and indispensible service to mankind." 92

One of these requirements is the obligation to conduct business with absolute honesty. ${ }^{93}$ Muslims must observe "absolute honesty in all business transactions in order to obtain Allah's blessings." 94 Muslim business owners who conduct business honestly "not only create economic prosperity and social harmony but also bring them[selves] closer to Allah." "As Allah fixes prices charged to customers through the market mechanism of supply and demand. ${ }^{96}$ Islamic religious teachings also impose limitations on the types of loans Muslims may offer or accept. In particular, the Qur'an prohibits lending or borrowing money at interest. ${ }^{97}$

Islamic rules for business also include a prohibition on providing illicit goods to others. The rationale behind this prohibition is "whatever is conducive towards what is prohibited is itself forbidden." 98 Muslim businesses cannot be "avenues for what is forbidden." 99 Thus, a Muslim is not permitted to sell alcohol to others in his store, because Allah prohibits the use of alcohol. ${ }^{100}$ Likewise, Islam prohibits providing other illicit goods, such as pigs and improperly slaughtered animals. "Business is meant by Allah to provide goods and services beneficial to mankind" and therefore "prohibits transactions in forbidden goods and services" with others. ${ }^{101}$

91 Id.; see also Hasan, supra notc 89, at 8 ("Islam aims at shaping all cxchange relations among people on the principle of cooperation, mutual benefit, and fair play.").

92 YUSOFF, supra note 88 , at 85.

93 THE MEANING OF THE HOLY QUR'AN, supra note 89, at $112 \mathrm{n} .314$ ("Islam will have nothing to do with tainted property. Its cconomic code requires that every gain should be honest and honourable.").

94 YUSOFF, supra notc 88, at 88; see also Hasan, supra notc 89, at 8 ("[Islam] advocates absolute honesty in business to the extent that one is enjoined not to falsely praise his merchandise, but to reveal to the customer.").

95 YusOFF, supra notc 88, at 85.

96 Id. at 88 ("This is a concept of business also accepted by the West. The difference is that Western cconomists regard the forces of supply and demands as 'an invisible hand' whereas Islam recognises it as Allah's Will.").

97 THE MEANING OF THE HOLY QUR'AN, supra note 89, at $115 \mathrm{nn} .324-25$ (stating that "usury is condemned and prohibited in the strongest possible terms" because "a dependence on usury would merely cncourage a race of idlers, cruel blood-suckers, and worthless fellows"); Hasan, supra notc 89, at 9 ("Barring a few discordant voices, learned opinion in the Muslim world holds, as an axiom, that the prohibition on riba is total and completc in Islam."). But see Mohammad F. Fadel, Riba, Efficiency, and Prudential Regulation: Preliminary Thoughts, 25 WIS. INT'L L.J. 655, 656 (2008) ("It is now generally recognized, at least among scholars, that Islamic law permits numerous transactions which at the very least incorporate implicit intcrest in their structure.").

98 YUSOF, supra note 88, at 231.

99 Id.

100 Id. at 230 ("The Prophet stated: When Allah prohibits a thing, He prohibits (giving and receiving) the price of it as well. (Ahmad and Abu Daud) Surely Allah and His Messenger have prohibited the sale of wine, the flesh of dead animals, swine and idols. (Al-Bukhari and Muslim).").

101 Id. 


\section{Three Examples of Religious Exercise by Profit-Making Corporations and Their Owners}

In light of the religious teachings set forth above, it is not surprising that there are some businesses and business owners who engage in religiously motivated actions during their profit-making activities. Some of these examples are unsurprising. Tyndale Publishing House, Inc., for example, publishes Bibles. ${ }^{102}$ Mardel Christian and Education is a Christian-themed bookstore. ${ }^{103}$ Although not legally organized as nonprofit entities, these businesses are religious in nature and necessarily involve some religiously motivated conduct. Religious beliefs seem very likely to motivate everyday decisions. For example, these businesses must decide which Bible translations to publish and which religious products to carry in a religious store.

This Section will consider three somewhat less obvious examples of profit-making businesses that purport to exercise religion: a gas station, a grocery store, and a craft store. Is it possible for businesses of this nature to exercise religion in the course of their profit-making endeavors? The business descriptions set forth below suggest that it is possible, and that at least some profit-making businesses engage in what can only fairly be called exercises of religion.

\section{Rio Gas Station and Heimeshe Coffee Shop, Brooklyn, New York}

As described above, Jewish religious sources impose several religious requirements for the conduct of business. ${ }^{104}$ Observant Jews seeking to comply with such requirements must take certain actions, and avoid certain actions, in accordance with religious requirements. Rio Gas Station in the Borough Park section of Brooklyn, New York, is operated according to such requirements. Borough Park is an area heavily populated with Hasidic Jews. When the owner, an observant Jew, purchased the gas station in 2005, he turned one bay of the garage into a kosher coffee shop, Heimeshe Coffee Shop. ${ }^{105}$

\footnotetext{
102 Tyndale House Publishers, Inc. v. Scbelius, 904 F. Supp. 2d 106, 111 (D.D.C. 2012).

103

See About Us, MARDEL CHRISTIAN \& EDUC., http://www.mardel.com/about/ (last visited Oct. 4, 2013).

104 See supra Part I.A.1.a.

105 See Reuven Fenton, B 'klyn Gas Stop a Kosher Delight, N.Y. Post (May 11, 2009, 5:35 AM), http://nypost.com/2009/05/11/bklyn-gas-stop-a-kosher-delight/. "Hcimcshe" (or "heimish") is Yiddish for "homey," in reference to the atmosphere, although its meaning and usage has evolved. See Heimish: What Does It Mean to You?, YeshIVA WORLD, http://www.theycshivaworld.com/coffccroom/ topic/heimish-what-does-it-mean-to-you (last visited Oct. 4, 2013).
} 
The gas station/kosher coffee shop is run according to at least two religious requirements. First, it serves only food prepared according to Jewish kosher restrictions. ${ }^{106}$ Second, it shuts down on for the Sabbath. ${ }^{107}$ These requirements are followed because the owner is an observant Jew who understands that his faith requires him to run his business in this manner. ${ }^{108}$

\section{Abdi Aden, Afrik Grocery, Inc., and Minneapolis's Alternative Financing Program}

Abdi Aden is a Somali immigrant who lives in Minneapolis, Minnesota. ${ }^{109}$ In 1998, he fled a civil war in Somalia that took the lives of members of his family. ${ }^{110}$ After traveling thousands of miles to Minneapolis, Aden set out to establish a small grocery store, just as he had owned in Mogadishu. ${ }^{111}$

Aden now owns Afrik Grocery and Halal Meat through a for-profit corporation, Afrik Grocery, Inc., which he established in 2004. Aden is the sole shareholder and chief executive officer. ${ }^{12}$ Aden operates Afrik Grocery in accordance with his Muslim religious beliefs. ${ }^{113}$ Aden's religious obligations prohibit him from allowing his business to participate in activities that would violate Islamic law. ${ }^{114}$ Thus, the halal meat at Afrik is prepared in accordance with Islamic requirements derived from the Qur'an. ${ }^{15}$ Likewise, Afrik Grocery cannot sell items like liquor, pork, or pornographic magazines. ${ }^{116}$ Aden's Muslim faith forbids him from providing these products to anyone else, as well as from personally consuming them. ${ }^{117}$

Aden's obligation to run Afrik Grocery according to his Muslim faith also controls the types of business loans his corporation may accept. ${ }^{118}$ In

\footnotetext{
106 Fenton, supra note 105.

107 Id.

108 Telephone Interview with Manager, Rio Gas Station, Brooklyn, N.Y. (Feb. 26, 2013).

109 Tclephone Interview with Abdi Aden, Owner, Afrik Grocery, Inc., Minneapolis, Minn. (Feb. 26, 2013).

110 Gwendolyn Freed, Careers Set Aside to Get Ahead in Life: East African Immigrants Often Work Far Below Their Skills to Get a Start Here, MINNEAPOLIS STAR TRIB., June 30, 2003, at A1, available at 2003 WLNR 14268362; see also Mark Anderson, Nonprofit Lenders Boost Immigrant Entrepreneurs, DULUTH NEWS-TRIB. (June 3, 2008), available at 2008 WLNR 10455846.

111 Anderson, supra note 110.

112 See Business Record of Afrik Grocery Inc., MINN. SEC. OF STATE, http://mblsportal. sos.state.mn.us/Business/SearchDetails?filingGuid=c661 d22d-88d4-e01 1-a886-001 cc94ffe7f (last visited Oct. 4, 2013) (showing formation of Afrik as a “domestic business" corporation in 2004); Telephone Interview with Aden, supra note 109.

113 Telephone Interview with Aden, supra note 109.

114 Id.

$115 \mathrm{Id}$.

116 Id.

$117 \mathrm{Id}$.

$118 \mathrm{Id}$.
} 
particular, due to his religious obligations, Aden is not permitted to allow Afrik Grocery, Inc. to take a loan that would require payment of interest. ${ }^{119}$

Fortunately for Aden, Minneapolis is home to a large number of Muslim immigrants, and the city has taken steps to make loans available that comply with Islamic law. ${ }^{120}$ Minneapolis has partnered with a local nonprofit, the African Development Center, to create the Alternative Financing Program. ${ }^{21}$ The Alternative Financing Program matches loans provided by small lenders and structures the loans in a way that is permissible under Islamic law. ${ }^{122}$ The program is not limited to Muslims but is open to applicants of any faith or no faith at all. ${ }^{123}$ The loans are structured in a way that avoids the Islamic prohibition on earning or paying interest, while still providing a fair market rate of return for the lender. ${ }^{24}$ According to the city, most loans are for between $\$ 5,000$ and $\$ 10,000$ and are repaid within three years. ${ }^{125}$

In 2005, Aden wanted to move Afrik Grocery down the street and expand his store to better serve his customers. ${ }^{126}$ In particular, Aden wanted to be able to expand his halal meat offerings but needed a loan that would comply with Islamic religious requirements to fund the expansion. ${ }^{127}$ Accordingly, Afrik Grocery took out a loan from Minneapolis's Alternative Financing Program. ${ }^{128}$ Aden was able to both secure the financing his business needed and to keep his business compliant with Islamic law. ${ }^{129}$ Aden borrowed $\$ 42,000$, expanded and relocated his store, and paid back the loan in full in 2009. ${ }^{130}$ Aden and Afrik Grocery clearly benefited from the availability of a business loan program recognizing that some for-profit businesses engage in religious exercise by conducting themselves in accordance with religious requirements. ${ }^{131}$

119 Telephone Interview with Aden, supra note 109.

120 See Rachel Stassen-Berger, Banking on Trust, ST. Paul PIONEER Press, Apr. 20, 2000, at 1B, available at 2000 WLNR 2239313 (noting "evidence points to a huge boom" of immigrant businesses in Minneapolis).

121 Nick Sudheimer, Minneapolis Helps Muslim Businesses Follow Sharia Law, MiNNESOTA DAILY (Feb. 7, 2012), http://www.mndaily.com/2012/02/07/minncapolis-hclps-muslim-businesses-follow-sharia-law; Press Release, African Development Center, ADC Partners with Minneapolis on New Business Financing Program (Mar. 22, 2007), available at http:/www.adcminnesota.org/page/adc-updatcs/bussiness-financing-program.

122 Sudheimer, supra note 121.

$123 \mathrm{Id}$

$124 \mathrm{Id}$

$125 \mathrm{Id}$.

$126 \mathrm{Id}$.

$127 \mathrm{Id}$.

128 Sudheimer, supra note 121.

129 Id.

$130 \mathrm{Id}$.

131 Not incidentally, the City of Minneapolis also benefits from this program. According to the City, as of 2009, the Alternative Financing Program had made 54 loans, only one of which ended in default. Id; Request from the Dept. of Cmty. Planning \& Econ. Dev. to Council Member Lisa Goodman, Cmty. 


\section{The Green Family and Hobby Lobby Stores, Inc.}

Like Abdi Aden, David Green started his business with a small loan from a local bank. Green used his $\$ 600$ loan to start a small frame company in 1970, which he originally operated out of his garage in Oklahoma. ${ }^{132}$ Today, Hobby Lobby Stores, Inc. is a craft store empire, with more than 500 stores, and more than 25,000 employees, spread over forty-five states. ${ }^{133}$ The stores are enormously successful financially, with annual sales over $\$ 2$ billion. ${ }^{134}$ In 2013, Green was listed as number seventy-nine in Forbes magazine's list of the wealthiest people in America, with a net worth of $\$ 4.5$ billion. ${ }^{135}$

From its inception, Hobby Lobby has been a family business which the Green family runs according to their Christian beliefs. ${ }^{136}$ The company's statement of purpose announces its commitment to "[h]onoring the Lord in all we do by operating the company in a manner consistent with Biblical principles." 137 The family members who run the company each sign a state-

Dev. Comm., and Council Member Betsy Hodges, Ways and Mcans/Budget Comm. 3 (Jan. 18, 2011), available at http:/www.minncapolismn.gov/www/groups/public/@council/documents/webcontent/convert_272900.pdf. This compares favorably with the much higher default rate on small busincss loans, which the Small Business Administration estimated at approximately 12 percent in 2009 . Sudheimer, supra note 121 . Furthermore, these loans presumably help individual businesses, their owners, their $\mathrm{cm}-$ ployees, and their families to be more prosperous and productive citizens and less likely to need government assistance in other ways.

132 Suzanne Jordan Brown, The Modest Billionare, Charisma MAG. (Oct. 5, 2012, 9:55 AM), http://www.charismamag.com/life/business-finance/1476-the-modest-billionaire.

133 Press Release, Congressmen Dianc Black, Jeff Fortenberry, and John Fleming, Black, Fortenberry, and Fleming Introduce Health Care Conscience Rights Act to Stop Obama Administration's Assault on Rcligious Freedom (Mar. 5, 2013), available at https://black.housc.gov/press-relcase/black-fortenberry-fleming-introducc-health-carc-consciencc-rights-act-stop-obama; Our Company, HOBBY LOBBY, http:/www.hobbylobby.com/our_company/ (last visited Oct. 4, 2013); Our Stores, HOBBY LOBBY, http://www.hobbylobby.com/stores/stores.cfm (last visited Oct. 4, 2013).

134 Eric Marrapodi, Hobby Lobby Finds Way Around \$1.3-Million-a-Day Obamacare Hit-for Now, CNN BELIEF BLOG (Jan. 11, 2013, 3:40 PM), http://religion.blogs.cnn.com/2013/01/1 1/hobby-lobbys-13-million-obamacare-loopholc/comment-page-41/.

135400 Richest Americans-David Green, FORBES, http:/www.forbes.com/profile/david-grcen/ (last visitcd Oct. 4, 2013).

136 See Verified Complaint at 2, Hobby Lobby v. Sebelius, 870 F.Supp.2d 1278 (W.D. Okla. 2012) (No. CIV-12-1000-HE) [hercinafter Hobby Lobby Complaint] (stating that the Green family's business operations "reflect their Christian faith in unmistakable and concrete ways" because they "belicve[] they are obligated to run their businesses in accordance with their faith"). See also DAVID GREEN \& DEAN

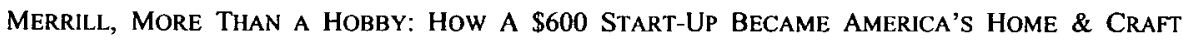
SUPERSTORE 198 (2005) ("There is a God, and he's not averse to business. He's not just a 'Sunday deity.' He understands margins and spreadsheets[,] competition and profits. Pleasing customers is important, but pleasing God through the way I run the business is even more important.").

137 Statement of Purpose, HOBBY LOBBY, http://www.hobbylobby.com/our_company/purpose.cfm (last visited Oct. 4, 2013). 
ment of faith and commitment, obligating them to conduct the business according to their religious beliefs and to "use the Green family assets to create, support, and leverage the efforts of Christian ministries."138

Hobby Lobby frequently takes action based on the Greens' Christian religious beliefs. ${ }^{139}$ All stores close on Sundays, at a cost of millions per year, to allow employees a day of rest. ${ }^{140}$ Christian music plays in the stores. ${ }^{141}$ The company pays for all employees to have cost-free access to chaplains, spiritual counseling, and religiously themed financial courses. ${ }^{142}$ Company profits provide millions of dollars per year to Christian ministries around the world. ${ }^{143}$

Hobby Lobby also frequently abstains from certain business practices, because the Greens' religious beliefs preclude them. For instance, because the Greens are religiously prohibited from promoting or facilitating alcohol use, Hobby Lobby does not sell shot glasses. ${ }^{144}$ Similarly, when a liquor store offered to assume a building lease in a deteriorating neighborhood, Hobby Lobby had to refuse - even though it would cost the company $\$ 3.3$ million dollars over the life of the lease. ${ }^{145}$ The Greens' religious beliefs also preclude them from allowing their trucks to "back-haul" beer, forcing them to forego substantial profits when they refuse offers from distributors. ${ }^{146}$ And while the Greens have no religious objection to standard contraception, their religion forbids them from providing insurance coverage for abortion or emergency contraception. The Greens, therefore, exclude those items from the company's health insurance offerings. ${ }^{147}$ As a matter of faith, the Greens cannot

138 Hobby Lobby Complaint, supra note 136, at 9 (internal quotation marks omitted); see also GREEN \& MERRILL, supra note 136, at 196 ("In order to keep giving, we necd to kecp growing Hobby Lobby and its affiliate companies. This is what energizes my day-to-day work in retailing now-the knowledge that if we can add stores and thereby boost profits, we can give away that much more to make a difference ctcrnally. I'll definitely get out of bed in the morning to see that happen!').

139 Hobby Lobby Complaint, supra note 136, at 2 (stating that the Greens diligently "monitor their merchandise, marketing, and operations to make sure all are consistent with" their religious obligations).

140 Id.

141 Id. at 11.

142 See id. at 13-14.

143 Id. at 2.

144 Id. at 11 .

145 GREEN \& MERRILL, supra note 136, at 143 (“I thought to myself, 'You know, that's just about the last thing this neighborhood necds. It's already got a bunch of problems - they don't need another big provider of alcohol in the community.").

146 Id. at 144 ("[O]ur trucks returning from our Colorado stores could have back-hauled Coors Beer to Oklahoma City on a long-term contract that would have netted us $\$ 300,000$ a year. It was a time when we really could have used the cash. But again, we said no thank you, preferring to let our trucks come back empty until we could find an alternative. Let someone else haul the beer and take the responsibility for what people do with it.").

147 Hobby Lobby Complaint, supra note 136, at 29. This is the religious exercise that has led to Hobby Lobby's current lawsuit against the federal government. Id. If Hobby Lobby and the Greens do 
engage in actions that run counter to their religion. Nor can they facilitate such actions through the behavior of their businesses.

Perhaps Hobby Lobby's most public religious exercise is its series of holiday ads, which began in 1997. The ads stem from David Green's belief that if his store spends money on advertising to sell its products fifty weeks a year, it should also be willing to spend money twice a year to tell people about the religious meaning of Christian religious holidays. ${ }^{148}$ The corporation's first ad, which appeared at Easter 1997, encouraged readers to "believe in the love that sent Jesus Christ. Accept the hope. Accept the joy. Accept the LIFE!" 149 Hobby Lobby Stores, Inc. placed, paid for, and signed the ad. ${ }^{50}$

The corporation has continued placing ads each Easter and Christmas since that time. Hobby Lobby's ads encourage people to know Jesus as Lord and Savior, and to call a provided phone number for religious counseling. ${ }^{151}$

Thus, as with Rio Gas Station and Afrik Grocery, Hobby Lobby demonstrates that some businesses are conducted according to religious beliefs. Actions taken, or abstained from, based on sincere religious beliefs are "religious exercises" under federal law. When Afrik Grocery makes a decision not to sell pork or not to take out standard and easily available loans, the business is clearly taking action based on religious beliefs. Indeed, it is difficult to fathom why the corporation would take these actions other than for a religious reason. When Rio Gas Station serves food prepared in accordance with ancient Jewish laws and stops serving food and pumping gas for the Sabbath, it too is taking actions based on religious beliefs.

Hobby Lobby's decisions about what products to sell and what activities the company will conduct are similarly based on religious beliefs. When the company creates advertisements encouraging people to know and love Jesus Christ, the business is engaged in the quintessential exercise of religion, namely, profession of faith. Indeed, it is difficult to think of a clearer example of a profit-making business engaging in a religious exercise than Hobby

not cease this religious exercise by July 2014 , they face fines that could run as high as $\$ 1.3$ million per day. $I d$.

148 See GREEN \& MERRILL, supra note 136, at 160 ("Every week I was already paying money to put out my message about the coming week's sale items. Couldn't I spend more of my money to spotlight the eternal importance of Christmas?").

149 Id. at 160-61. The full ad read as follows: "For God so loved the world he gave acceptance, peace, mercy, confidence, purpose, forgiveness, simplicity, hope, relief, comfort, equality, life, his Son. This Easter, we cncourage you to believe in the love that sent Jesus Christ. Accept the hope. Accept the joy. Accept the LIFE! Hobby Lobby Stores, Inc." Id.

150 Id.

151 See Holiday Messages, HOBBY LOBBY, http:/www.hobbylobby.com/holiday_messages/ (last visited Oct. 4, 2013) (featuring a complete collection of Hobby Lobby's advertisements). 
Lobby's holiday ads: if encouraging people to "know Jesus as Lord and Savior" is not an "exercise of religion," nothing is. ${ }^{152}$

Therefore, many religions impose, and at least some businesses follow, religious requirements for their profit-making activities.

\section{The Profit Distinction AND THE LAW}

As Part I establishes, the argument against religious liberty for profit makers cannot be based on a factual claim about either the demands of religion or the actions of religious business owners and their businesses. As a legal matter, however, the government argues that profit-making businesses cannot engage in the "exercise of religion" sufficient to come within the protection of the First Amendment's Free Exercise Clause or the federal Religious Freedom Restoration Act. ${ }^{153}$ In advancing this argument, the government relies on Title VII of the 1964 Civil Rights Act as its source for the categorical rule that profit-making entities cannot engage in religion. ${ }^{154}$

This Part of the Article explores the significance of the distinction between for-profit and nonprofit entities more broadly. The goal is to determine how, when, and whether the law treats the for-profit/nonprofit distinction as determinative of an organization's legal rights and capabilities. Is there something about how the law treats profit-making businesses and their owners that is incompatible with recognizing religious liberty rights for profit makers? The significance of the profit distinction will be examined in five different areas: businesses' ethical decision making (Part II.A); criminal law (Part II.B); Title VII discrimination law (Part II.C); tax law (Part II.D); and constitutional law (Part II.E).

Three important principles emerge. First, for-profit businesses are generally treated as capable of making subjective decisions based on values other than mere profit seeking. Second, in most areas of the law, the for-profit/nonprofit distinction has no bearing on the rights and capabilities of an organization. In the few areas where the profit distinction seems to matter, it does not suggest the kind of categorical rule the government proffers in the HHS mandate context - namely, that profit making and religious exercise are fundamentally incompatible. Third, business owners are regularly treated as responsive to, and capable of being pressured by, penalties imposed on their businesses.

Emp't Div., Dep't of Human Res. of Or. v. Smith, 494 U.S. 872, 877 (1990) (noting that the free exercise of religion "first and foremost" includes "the right to believe and profess whatever religious doctrinc one desires").

153 See DOJ Hercules Motion to Dismiss, supra note 2, at 17.

154 See Appellee's Opening Brief at 16, Ncwland v. Sebelius, No. 12-1380 (10th Cir. Feb. 22, 2013) [hereinafter Hercules App. Br.]; see also Coverage of Certain Preventive Services Under the Affordable Carc Act, 78 Fed. Reg. 8456, 8462 (Fcb. 6, 2013) (to be codified at 45 C.F.R. pts. 147, 148, \& 156). 


\section{A. Ethical Decision Making by Profit-Making Businesses}

There is no doubt that nonprofit organizations may organize around ethical, philosophical, or religious commitments other than profit making. ${ }^{155} \mathrm{Can}$ profit-making businesses incorporate such principles into their decision making as well?

Famed economist Milton Friedman once proclaimed: "[T]here is one and only one social responsibility of business - to use its resources and engage in activities designed to increase profits ...."156 This view is not unique to Friedman. In fact, several courts embracing the government's theory that business cannot engage in religious exercise have made the same claim: the only goal of a profit-making business is making profits. ${ }^{157}$

On the other hand, in common parlance, society often asks and expects businesses to "do the right thing" and avoid "irresponsible" behavior. ${ }^{158}$ Businesses are regularly referred to as being "greedy"159 or "generous,"160 "ethical"161 or "unethical."162 President Obama recently urged future business leaders to avoid simply pursuing profits and instead think about "what broader purpose your business might serve, in putting people to work or transforming a neighborhood."163

155 See I.R.C. $\S 501$ (c)(3) (2006 \& Supp. V 2012) (providing exempt status for groups pursuing, inter alia, religious, charitable, literary, or educational goals).

156 See Milton Fricdman, A Friedman Doctrine-The Social Responsibility of Business Is to Increase Its Profits, N.Y. Times, Scpt. 13, 1970, at SM17 (quoting MiLTON FRIEDMAN, CAPITALISM AND FREEDOM 133 (2002)) (internal quotation marks omitted).

157 See, e.g., Conestoga Wood Specialties Corp. v. Scbelius, No. 13-1144, slip op. at 3 (3d Cir. Jan. 29,2013 ) (Garth, J., concurring) (noting that the mission of Conestoga, "like that of any other for-profit, secular business, is to make money in the commercial sphere").

158 See, e.g., President Barack Obama, Weckly Address (Jan. 26, 2013) (transcript available at http://www.whitchouse.gov/the-press-office/2013/01/25/weekly-address-two-nominees-who-will-fightamerican-people) (citing the need to "make sure businesses and individuals who do the right thing aren't undermined by those who don't").

159 See, e.g., John Hendren, Obama: Wall Street 'Arrogance and Greed' Won't Be Tolerated, ABC NEwS (Jan. 31, 2009), http://abcnews.go.com/Politics/CEOProfiles/story?id=6778419\&page=1 (quoting President Obama saying the American pcople will not excuse "arrogance and greed" from "Wall Strect firms" that have acted "shamefully" by paying large bonuses after accepting taxpayer bailouts).

160 See, e.g., Matthew Kirdahy, America's Most Generous Corporations, FORBES.COM (Oct. 16, 2008, 6:00 PM), http://www.forbes.com/2008/10/16/most-generous-corporations-corprespons08-leadcx_mk_1016charity.html (citing research by the Chronicle of Philanthropy about the "giving habits" of seventy-cight of the nation's largest corporations).

161 See, e.g., Jacquelyn Smith, The World's Most Ethical Companies, FORBES.COM (Mar. 15, 2012, 10:09 AM), http://www.forbes.com/sites/jacquelynsmith/2012/03/15/the-worlds-most-ethical-companies/ (ranking 150 of the world's "most ethical companies").

162 See, e.g., Beth Braverman, 'Unethical Behavior' to Blame for Gas Prices-Poll, CNN.COM (Junc 11, 2008, 3:15 PM), http://money.cnn.com/2008/06/11/news/economy/gas_poll/index.htm ("A poll released Wednesday finds that $62 \%$ of Americans blame 'unethical behavior' by industry players.").

163 President Barack Obama, Remarks at Morehouse College Commencement Ceremony (May 19, 2013), http://www.whitehouse.gov/the-press-office/2013/05/19/remarks-president-morehouse-college- 
For nearly a century, scholars have discussed the role of "corporate social responsibility," or ("CSR"), in business management. ${ }^{164}$ The idea behind CSR is that directors of a business corporation should not focus exclusively on profit making. Instead, businesses should consider the impact of the business's actions on a variety of stakeholders, such as the company's employees, its customers, the community, or the environment. ${ }^{165}$ The notion of CSR is not limited to corporations, but rather extends to any business entity "regardless of the specific form of the business-partnership, contractual joint venture, entity joint venture, or even . . . loosely affiliated individuals coming together in a temporary constellation for a particular project."166 Vigorous debates remain ongoing about how, and whether, CSR should become a legally required part of business decision making. ${ }^{167}$

As a practical matter, many profit-making businesses do consider broader interests when making decisions, regardless of whether they have a legal duty to do so. ${ }^{168}$ State corporate laws broadly allow for-profit businesses to pursue any lawful purpose. ${ }^{169}$ Several states and the federal government

commencement-ceremony. The President's remarks cchoed his remarks a year carlier at a National Prayer Breakfast, in which he urged, "We can't leave our values at the door. If we leave our values at the door, we abandon much of the moral glue that has held our nation together for centuries." President Barack Obama, Remarks at National Prayer Breakfast (Fcb. 2, 2012), http://www.whitchousc.gov/the-press-office/2012/02/02/remarks-president-national-praycr-breakfast.

164 See C.A. Harwell Wclls, The Cycles of Corporate Social Responsibility: An Historical Retrospective for the Twenty-First Century, 51 U. KAN. L. REv. 77, 78 (2002) (dating scholarly debate to the 1930s); see generally LYNN STOUT, CULTIVATING CONSCIENCE: HOW GOOD LAWS MAKE GOOD PEOPLE (2011); Lynn A. Stout, On the Proper Motives of Corporate Directors (Or, Why You Don't Want to Invite Homo Economicus to Join Your Board), 28 DEL. J. CORP. L. 1 (2003).

165 See Wells, supra note 164, at 78; see also J. MARK RAMSEYER, BUSINESS ORGANIZATIONS 113 (2012) (" $[M]$ any of the people with the most lucrative business plans discover those plans because they love what they do. They do not work to make money. They work to have fun or do good.... Some of the most wildly creative and profitable ideas in business, in other words, come from men and women who do not self-consciously try to maximize their profits.").

166 Joc W. (Chip) Pitts III, Corporate Social Responsibility: Current Status and Future Evolution, 6 RUTGERS J.L. \& PUB. POL'Y 334, 421 (2009).

167 See, e.g., Margarct M. Blair \& Lynn A. Stout, A Team Production Theory of Corporate Law, 85 VA. L. REV. 247 passim (1999) (suggesting that corporate boards are required to balance interests of shareholders with those of management and employees); Cynthia A. Williams, The Securities and Exchange Commission and Corporate Social Transparency, 112 HARV. L. REV. 1197 passim (1999) (suggesting that the SEC require corporations to provide a public social disclosure).

168 See, e.g., Z. Jill Barclift, Too Big to Fail, Too Big Not to Know: Financial Firms and Corporate Social Responsibility, 25 J.C.R. \& ECON. DEv. 449, 467 (2011) ("In the U.S and internationally, CSR is now recognized as a part of overall corporate business strategy, as evidenced by the many organizations and companies touting CSR as an appropriate business model, the increased number of consultants advising businesses on the appropriatc CSR focus, and the number of companies advertising CSR initiatives. Business leaders have embraced CSR as a moral imperative because corporations have significant economic and political power in society. Firms are expected to utilize corporate powers in a socially responsible way." (footnotes omitted)).

169 See, e.g., IA William MEAde Fletcher, Fletcher Cyclopedia of the LAW OF CORPORATIONS $\S 102$ (rev. cd. 2010) ("“[A]ll jurisdictions permit the formation of a corporation for any 
have taken steps to ensure their laws expressly embrace the notion of the conscientious profit-making business. ${ }^{170}$

Many for-profit businesses voluntarily operate in a socially conscious manner. Whole Foods Market, Inc., for example, strives to "balance our needs with the rest of the planet" by promoting "environmental stewardship so that the earth continues to flourish for generations to come." 171 The store has adopted a set of "animal welfare standards" concerning the treatment of animals used for meat in their stores. ${ }^{172}$ Chipotle Mexican Grill, Inc. takes similar stands, promising to serve only foods "that are grown or raised with respect for the environment, animals and people who grow or raise the

lawful purpose or business ...."). For example, Oklahoma's corporations statute is "applicable to every corporation, whether profit or not for profit" and allows corporations to "promote any lawful business or purposes." OKLA. STAT. tit. 18, $\S \S 1002,1005$ (West 1999). The State of Oklahoma recently filed a brief in the Hobby Lobby litigation arguing that, under this provision, Hobby Lobby is permitted under state law to excrcise religion while earning profits. See Brief of the State of Oklahoma as Amicus Curiac in Support of Plaintiffs-Appellants and in Favor of Reversal of the Judgment Below at 7, Hobby Lobby, Inc. v. Scbclius, 2013 WL 3216103 (10th Cir. June 27, 2013) (No. 12-6294), available at http://www.bccketfund.org/wp-content/uploads/2013/02/State-of-Oklahoma.pdf ("[A] lawful purpose of any corporation organized under the Oklahoma General Corporation Act may be to express the views and even the religious beliefs and actions of its owners and the persons who operate it.").

170 See, e.g., Jonathan D. Springer, Corporate Constituency Statutes: Hollow Hopes and False Fears, 1999 ANN. SURV. AM. L. 85, 85 (stating that since the 1980s, more than thirty states have enacted "constituency statutes," cxpressly permitting directors to consider broader interests than mere shareholder profit-maximization). More recently, states have been experimenting with new corporate forms to further encourage the use of profit-making entities to pursue publicly beneficial goals. See, e.g., Felicia R. Resor, Comment, Benefit Corporation Legislation, 12 WYO. L. REV. 91, 92 (2012) ("In a growing number of states, lawmakers have passed legislation creating various new business entities to house social enterprise and organizations that blend for-profit and not-for-profit purposes."). Ronald Colombo has discussed these changes to corporate law in detail and argued for free exercise rights for corporations. See Colombo, supra note 24 (manuscript at 5). The Securities and Exchange Commission recently promulgated regulations concerning trade in "conflict minerals" to address congressional concerns about their role in fueling a humanitarian crisis in the Democratic Republic of the Congo. Conflict Minerals, 77 Fed. Reg. 56274, 56275 (Scpt. 12, 2012) (to be codificd at 17 C.F.R. $\$ \S 240,249$ \& 249b) ("To accomplish the goal of helping end the human rights abuses in the DRC caused by the conflict, Congress chose to use the securities laws disclosure requirements to bring greater public awareness of the source of issuers' conflict minerals and to promote the exercise of due diligence on conflict mineral supply chains.").

171 See Declaration of Interdependence, WHOLE FOODS, http://www.wholefoodsmarket.com/mission-values/core-values/declaration-interdependence (last visited Oct. 4, 2013).

172 See Animal Welfare Standards, WHOLE FOODS, http://www.wholefoodsmarket.com/about-ourproducts/quality-standards/animal-welfare-standards (last visited Oct. 4, 2013) ("It's often easy to forget that the burger, steak or drumstick on your plate was once an animal. How was that animal raised? How was it treated? Where did it come from? What about added hormones and antibiotics? Was its growth artificially accelerated to get to market sooner and reduce feed cost?'). Under these standards, there are certain types of meat that the store simply will not sell based on its beliefs about animal treatment. Id. Further, when the company does sell meat, it is carefully labeled according to a color-coded system to reflect how well the animal was treated during its life. $I d$. The company has partnered with an independent auditor to oversec and verify that it does not purchase meat from animals that have not met the company's animal welfare standards. $I d$. 
food." 173 NOOCH Vegan Market, LLC in Denver sells no animal products at all because its owners "believe that animals have the right to be free from human use and see NOOCH as an extension of that ideology."174

In addition to such profit-making businesses making subjective, valuesbased decisions, there are also nonprofit organizations that use investment in for-profit businesses as a way of advancing socially beneficial goals. For example, the Healthstore Foundation is a nonprofit entity that invests in forprofit businesses " $t$ t]o improve access to essential drugs, basic healthcare, and prevention services for children and families in the developing world." 175 A 2012 Harvard Business School case study suggests the organization is considering becoming a for-profit enterprise based on the belief of some in the organization that "only a for-profit could attract investor capital . . . to rapidly grow the business and ultimately enable HSF to scale to the size of large commercial franchise businesses." 176 Acumen Fund is a nonprofit investment fund investing in profit-making enterprises in the developing world because of its belief that "[m]arket-based approaches have the potential to grow when charitable dollars run out, and they must be part of the solution to the big problem of poverty."177 These entities further demonstrate the use of the profit-based model for purposes other than wealth maximization.

Although none of these organizations purports to be exercising religion, the examples are important to the religious liberty question because they suggest Americans regularly encounter, and accept, the notion of profit-making businesses taking actions based on ethical, philosophical, and moral commitments. If profit-making businesses are capable of forming subjective beliefs about such issues and acting on them, it is difficult to see how or why they would be precluded from forming and acting upon subjective beliefs about religion. In short, the example of companies like Acumen Fund suggests there is nothing inherent in the nature of for-profit businesses which forces those organizations to pursue profit and forsake all other values. ${ }^{178}$

173 Chipotle, Annual Report (Form 10-K) (Feb. 8, 2013).

174 About, NOOCH VEGAN MARKET, http://noochveganmarkct.tumblr.com/about (last visited Oct. 4, 2013).

175 Our Mission, HEALTH STORE FOUND., http://www.cfwshops.org/ (last visitcd Oct. 4, 2013).

176 See V. Kasturi Rangan \& Katherine Lee, CFW Clinics in Kenya: To Profit or Not for PROFIT 1 (2012).

177 ACUMEN FUND, DISCUSSION GUIDE FOR THE BLUE SWEATER 10 (2009), http://acumen.org/bluesweater/Book\%20club\%20discussion\%20guide.pdf (stating Acumen Fund's philosophy).

178 See also VISCHER, supra note 24, at 180 (arguing for corporate conscience and discussing WalMart's various conscience-based decisions, including a now-abandoned decision not to sell emergency contraccptives for moral reasons). In addition to such profit-making businesses making subjective, valuesbased decisions, there are also nonprofit organizations that use investment in for-profit businesses as a way of advancing socially bencficial goals. See, e.g., Our Mission, supra notc 175 (stating that Healthstore Foundation's mission is "[ $[$ ] improve access to essential drugs, basic healtheare, and prevention services for children and families in the developing world"). A 2012 Harvard Business School case study suggests the organization is considering becoming a for-profit cnterprise based on the belief of some in the organization that "only a for-profit could attract investor capital . . . to rapidly grow the business and ultimatcly 


\section{B. Profit-Making Businesses and Criminal Liability}

Generally speaking, criminal law assigns punishment in accordance with moral responsibility. While other values are of course at work, criminal punishment is deemed acceptable because of a belief that the perpetrator was morally responsible for doing wrong. ${ }^{179}$ This notion of moral responsibility explains why criminal laws treat children differently from adults, and the mentally ill differently from the unimpaired. ${ }^{180}$

Can a for-profit entity have "moral" responsibility for its actions, such that it is appropriate to hold the entity criminally liable? Do our laws treat organizations as capable of acting with the relevant mental state or mens rea required for criminal liability? Is there a categorical distinction between forprofits and nonprofits in this field?

After some early disputes on the matter, the modern answers are clear: both for-profit and nonprofit entities can be held criminally liable for their actions. ${ }^{181}$ Some early Supreme Court decisions rejected the notion that corporations could be treated similarly to natural persons, even for purposes of suing and being sued in federal court under diversity jurisdiction. ${ }^{182}$ For example, Chief Justice Marshall explained in 1809 that a corporation is an "invisible, intangible, and artificial being, [a] mere legal entity . . . certainly not

enable HSF to scale to the size of large commercial franchise businesses." RANGAN \& LEE, supra notc 176, at 1. Similarly, Acumen Fund is a nonprofit investment fund investing in profit-making enterprises in the developing world because of its belief that "[m]arket-based approaches have the potential to grow when charitable dollars run out, and they must be part of the solution to the big problem of poverty." ACUMEN FUND, supra note 177, at 10. These entities further demonstrate the use of the profit-based model for purposes other than wealth maximization.

179 See, e.g., Old Chicf v. United States, 519 U.S. 172, $187-88$ (1997) (noting that a criminal prosecutor must not only prove facts, but must do so in a way sufficient "to implicate the law's moral underpinnings and a juror's obligation to sit in judgment. Thus, the prosecutor may fairly seek to place its evidence before the jury ... to convince the jurors that a guilty verdict would be morally reasonablc"); Tison v. Arizona, 481 U.S. 137, 171 (1987) (Brennan, J., dissenting) (noting “"the relation between criminal liability and moral culpability' on which criminal justice depends") (quoting Pcople v. Washington, 62 Cal. 2d 777, 783 (1965)); Furman v. Georgia, 408 U.S. 238, 342-43 (1972) (Marshall, J., concurring) ("Men may punish for any number of reasons, but the one reason that punishment is morally good or morally justifiable is that someone has broken the law.").

180 See Roper v. Simmons, 543 U.S. 551, 570 (2005) (finding capital punishment is impermissible for juveniles because "[t]he susceptibility of juveniles to immature and irrational bchavior means 'their irresponsible conduct is not as morally reprehensible as that of an adult"') (quoting Thompson v. Oklahoma, 487 U.S. 815, 835 (1988)); Atkins v. Virginia, 536 U.S. 304, 320 (2002) (finding capital punishment impermissible for the mentally impaired because "cognitive and behavioral impairments make these defendants less morally culpable”).

181 See, e.g., United States v. Cincotta, 689 F.2d 238, 241 (1st Cir. 1982); Chames v. Cent. City Opera House Ass'n, 773 P.2d 546, 553-54 (Colo. 1989) (cn banc); In re Rule Amendments to Rules 5.4(a) and 7.2(c) of the Rules of Prof'l Conduct, 815 A.2d 47, 49, 52 (R.I. 2002) (per curiam).

182 Bank of the United States v. DeVeaux, 9 U.S. (5 Cranch) 61, 86-87 (1809). 
a citizen .... ."183 Therefore, Marshall concluded that a corporation "cannot come within the description of those who are entitled to sue in the circuit courts of the United States." 184

By 1853 , the Court reversed itself and held that corporations can be citizens for diversity purposes. ${ }^{185}$ And as business corporations grew in prominence throughout the nineteenth century, so too did efforts to regulate corporations with criminal law. ${ }^{186}$ The issue reached the Supreme Court again in New York Central \& Hudson River Railroad Co. v. United States. ${ }^{187}$ The case concerned a New York criminal law punishing the railroad company for paying illegal rebates. ${ }^{188}$ The Court noted early authorities' finding that a corporation could not be held liable for a crime. ${ }^{189}$ But, the Court found that " $[t]$ he modern authority, universally, so far as we know, is the other way." $190 \mathrm{Re}$ jecting corporate criminal liability could only be supported by "the old and exploded doctrine that a corporation cannot commit a crime." 191

Today, for-profit businesses can be held liable for a wide variety of crimes. ${ }^{192}$ By definition, this means that the law recognizes it is possible for a corporation to form the relevant criminal law mens rea for various crimes. ${ }^{193}$ There are two predominant models for such corporate criminal liability. First,

$183 \mathrm{ld}$

184 Id.

185 Marshall v. Balt. \& Ohio R.R. Co., 57 U.S. 314, 328-29 (1853).

186 See George Skupski, The Senior Management Mens Rea: Another Stab at a Workable Integration of Organizational Culpability into Corporate Criminal Liability, 62 CASE W. RES. L. REV. 263, 266-67 (2011) ("Throughout the nineteenth century, the 'corporation as a fiction' view was progressively rejected as the corporation became more dominant in American society.").

187212 U.S. 481, 494-96 (1909).

188 Id. at $489-92$.

189 ld. at $491-93$

190 Id. at 492.

191 Id. at $495-96$

192 See V.S. Khanna, Corporate Criminal Liability: What Purpose Does It Serve?, 109 HaRV. L. REV. 1477, 1488 (1996) ("The scope of corporate criminal liability in the United States is very broad. A corporation may be criminally liable for almost any crime except acts manifestly requiring commission by natural persons, such as rape and murder."). For example, the federal government recently filed an information against British Petroleum, accusing the corporation of felony manslaughter during the Deepwater Horizon accident. Mike Scarcella, BP Agrees to Record Criminal Penalty in Gulf of Mexico Oil Spill, NAT'L L.J. (Nov. 15, 2012), http://www.law.com/jsp/nlj/PubArticlcNLJ.jsp?id=1202578529316 ("The explosion of the rig was a disaster that resulted from BP's culture of privileging profit over prudence; and we allege that BP's most senior decisionmakers onboard the Decpwater Horizon negligently caused the explosion,' Assistant Attorney General Lanny Breuer, the head of the DOJ Criminal Division, said in a statement." (emphasis omitted)).

193 William S. Laufer, Culpability and the Sentencing of Corporations, 71 NEB. L. REv. 1049, 1059 (1992) ("II]t is axiomatic that theorics of criminal punishment require the finding of mens rea."); see also Lawrence Friedman, In Defense of Corporate Criminal Liability, 23 HARV. J.L. \& PUB. POL'Y 833, 848 (2000) ("The modern corporation also can be substantively distinguished from its owners, managers and employees by its capacity to express independent moral judgments in the discourse of the public square, and so to participate in the process of creating and defining social norms."). 
and most commonly, courts sometimes find the corporation liable for their employees' criminal actions through the doctrine of respondeat superior. ${ }^{194}$ The mental state of the employee acting within the scope of his or her employment and for the company's benefit is imputed to the corporation itself. ${ }^{195}$ Some jurisdictions take a somewhat narrower view and hold the corporation liable only if an officer or manager of the company forms the mental state. ${ }^{196}$

An entity's status as a for-profit or nonprofit organization has no bearing on whether the entity can be held liable under criminal law. For example, the Colorado Supreme Court has rejected claims that a nonprofit corporation should be considered categorically incapable of violating a state criminal statute prohibiting gambling. ${ }^{197}$ The nonprofit argued its status was dispositive. It claimed the fundraising gala could not have violated the criminal law, because the nonprofit could not form the requisite intent to profit from gambling. The court rejected the nonprofit's claim, finding that even a nonprofit entity could form the requisite mental intent to be found guilty of profiting from illegal gambling. ${ }^{198}$

Notably, the organization's criminal liability does not have any impact on the liability of the employees or officers involved, who may also be separately held liable under criminal law. ${ }^{199}$ In the corporate realm, the law often

194 Federal law tends to follow this respondeat superior theory of corporate criminal liability. See Laufer, supra note 193, at 1055 ("Courts interpreting federal statutory law find corporations criminally liable for the conduct of employees acting within the scope of employment or with apparent authority, and with an intent to benefit the corporation.").

195 Id. at $1055-56$.

196 This approach is taken in some states, and is the approach suggested by the Model Penal Code. See id. at 1058 (noting that under state law, liability is available either through respondeat superior theory, or where "the "offense was authorized, requested, commanded, performed or recklessly tolerated by the board of directors or by a high managerial agent acting in behalf of the corporation within the scope of his office or employment"' (quoting MODEL PENAL CODE $\$ 2.07(1)(c)$ (Proposed Official Draft 1962))).

197 Charnes v. Cent. City Opera House Ass'n, 773 P.2d 546, 553-54 (Colo. 1989) (en banc).

198 Id. at 554 ("The fact that the revenues gencrated by the Gala were not distributed to members, directors, or officers of the association did not preclude the association from realizing or from intending to realize a 'benefit,' and thus a profit, from the Gala. We thus conclude that the Opera House Association aided the Gala invitees in gambling, that it did so with the intent to realize a direct profit therefrom, and that it thereby participated in 'professional gambling."'). The Rhode Island Supreme Court has likewise indicated that nonprofit corporations can violate criminal law. See In re Rule Amendments to Rules 5.4(a) \& 7.2(c) of the Rules of Prof'l Conduct, 815 A.2d 47, 52 (R.I. 2002) (noting that an agreement by a nonprofit corporation unauthorized to practice law to receive a share of attorney's fees would be impermissible in its own right and "as a conspiracy, a separate criminal offense that is committed at the very moment the agreement is made").

199 See 18B AM. JUR. 2D Corporations $\$ 1841$ (2004) ("Although a corporate crime is based on the acts of its employees or agents, the corporation is a separate entity and is severally liable ... for its crimes. ... [B]ecause its liability is separate from that of its officers or employces, both the corporation and the individual who committed the act may be found guilty, and the conviction of the responsible officers is not a bar to the prosecution of the corporation itself." (footnotes omitted)). 
treats both the individual actor and the corporate entity as criminally responsible when an actor engages in a criminal act for the company. ${ }^{200} \mathrm{~A}$ business owner who commits a crime for the business may find that both he and his business are criminally liable. In fact, many states have statutes expressly addressing the subject and clarifying that an individual who commits a crime for a corporation remains personally liable for the offense. ${ }^{201}$

Why would the law impose liability on both the organization and the individual actor? Liability for the employees or managers imposes an individualized deterrent on that particular actor. Liability for the corporation, however, reduces the corporation's net worth and thereby can impose substantial pressure on the corporation's owners (i.e., shareholders). ${ }^{202}$ Shareholders will then have an incentive to encourage managers not to engage in the proscribed behaviors. ${ }^{203}$ As Judge Richard Posner has explained, "if the

$200 I d$; see also Press Release, U.S. Dep't of Justice, Canadian Citizen Sentenced in Scheme to Defraud Consumers Purchasing Pharmaceuticals Online (Jan. 9, 2013), available at http://www.justice.gov/opa/pr/2013/January/13-civ-035.html (noting that a target was sentenced to four years in prison for "conspiracy to commit mail fraud in connection with his role as owner and president of Mediplan Health Consulting, Inc., a Canadian company"). Indeed, the Supreme Court has unanimously held that the sole shareholder of a corporation can be found separately guilty of illegally conspiring with the corporation under the Racketeer Influence and Corrupt Organizations Act (RICO), even when the shareholder acted within the scope of his corporate employment. Cedric Kushner Promotions, Ltd. v. King, 533 U.S. $158,164-66$ (2001).

201 See, e.g., AlA. CODE § 13A-2-26 (2012); see also Colo. REV. STAT. § 18-1-607 (2012) ("A person is criminally liable for conduct constituting an offense which he performs or causes to occur in the name of or in bchalf of a corporation to the same extent as if that conduct were performed or caused by him in his own name or bchalf."); KY. REV. STAT. ANN. $\S 502.060$ (West Supp. 2007) (“A person is criminally liable for conduct constituting an offense which he performs or causes to be performed in the name of or in behalf of a corporation to the same extent as if the conduct were performed in his own name or behalf.").

202 Khanna, supra note 192, at 1495 ("Direct liability, as its name indicates, directly influences managers' or employees' behavior by imposing penalties on these agents whenever they commit certain undesirable acts. Corporatc liability works more indirectly. Imposing sanctions on a corporation for the acts of its managers or employees presumably decreases the corporation's net worth. Shareholders, who bear the brunt of such a decrease, have an incentive to encourage managers not to commit undesirable acts (assuming that any benefits from the acts do not outweigh the costs to the shareholders). Shareholders can influence the behavior of corporation managers and employees in a number of ways, such as by modifying employment contracts to provide incentives not to engage in certain types of activitics." (footnotes omitted)); see also id. at 1494 (noting that many commentators and judges view deterrence, not retribution, as the aim of corporate criminal and civil liability).

203 See, e.g., SEC v. Med. Comm. for Human Rights, 404 U.S. 403, 404-06 (1972) (addressing a shareholder proxy proposal to prohibit Dow Chemical Company from selling napalm during the Vietnam War); Katherina Glac, The Influence of Shareholders on Corporate Social Responsibility 11 (Ctr. for Ethical Bus. Cultures, Working Paper No. 2, 2010), available at http://www.cebcglobal.org/uploaded_files/Glac_paper_on_Social_Investment_FINAL.pdf (describing how "faith-based" institutional investors use sharcholder proposals to influence companics); see also RESPONSIBLE ENDOWMENTS COALITION, http://cndowmentethics.org (last visited Oct. 4, 2013) ("Responsible investment means recognizing that our finances have major social and environmental impacts worldwide-from peoples' working conditions, to their health, to the very land they live on."). 
shareholders bear no responsibility for a manager's crime they will have every incentive to hire managers willing to commit crimes on the corporation's behalf." ${ }^{204}$ In this respect, the entire concept of criminal liability for for-profit corporations depends on the view that a corporation's owners can be pressured by penalties imposed upon the business. ${ }^{205}$

Thus it is clear that for-profit and nonprofit businesses can be held liable for their crimes, and are understood as able to form the subjective mental intent necessary for criminal liability. This application of criminal law is driven, at least in part, by a view that the criminal corporation has done something morally wrong and by a desire to impose pressure on shareholders to encourage more responsible behavior. Moreover, this criminal liability for the business is in addition to liability faced by the natural persons who engaged in criminal activity on behalf of the corporation.

Engaging in religious exercise, of course, is not a criminal offense. Still, criminal law's treatment of for-profit businesses and their owners is relevant to the religious liberty question. It is unclear what principled reason would justify viewing a corporation as capable of forming and acting upon criminal intentions but incapable of forming and acting upon religious ones. Moreover, it is at the very least odd to think that American criminal laws would deem a business and responsible individuals both criminally responsible for their crimes, but that religious liberty law would treat neither as capable of asserting civil rights under religious liberty law. Finally, the corporate criminal law exists as a system designed to penalize companies and thereby create incentives for owners to behave in particular ways. The owners of businesses are, therefore, understood as responsive to penalties imposed on their businesses. This suggests, in the religious liberty context, the threat of a penalty against the business should be expected to create substantial pressure on the business owner.

\section{Title VII Discrimination Law}

The government relies on a reference to Title VII discrimination law as the basis for treating for-profit businesses as incapable of exercising religion. ${ }^{206}$ The government argues that because there are no decisions finding that for-profit businesses qualify under Title VII's "religious organization" exception (which allows organizations to discriminate based on religion when hiring employees), for-profit businesses must be categorically incapable of religious exercise of any kind under any federal law. ${ }^{207}$ This Section will explore whether Title VII discrimination law actually treats for-profit

Id.

206 DOJ Hercules Motion to Dismiss, supra note 2, at 17 (citing 42 U.S.C. $\$ 2000 \mathrm{bb}-1$ (a) (2006)). 
businesses as incapable of exercising religion, and whether Title VII supports the broad exclusion of for-profit businesses from other religious liberty laws.

\section{Title VII's Prohibition on Religious Discrimination Against Employees}

Title VII generally prohibits employment discrimination based on certain protected traits, including religion. ${ }^{208}$ Title VII's broad definition of "religion" includes not just religious belief or identity but "all aspects of religious observance and practice, as well as belief." ${ }^{09}$ Employers must reasonably accommodate all of their employees' religious practices unless accommodations would cause undue hardship. ${ }^{210}$ In this respect, Title VII's primary impact on religious liberty is to ensure that employees can earn money without facing discrimination and unnecessary burdens on their religious practices and beliefs.

To achieve this goal, Title VII imposes liability on the employer, rather than the individual supervisor engaged in religious discrimination. ${ }^{211}$ Why impose liability on the employer? The answer is the same as in the corporate crime analysis: imposing liability on the company puts pressure on the company's owners to take action to eliminate discrimination. ${ }^{212}$ As the Supreme Court has explained, the prospect of damages awarded against the company under Title VII is designed to "provide[] the spur or catalyst which causes employers and unions to self-examine and to self-evaluate their employment practices and to endeavor to eliminate, so far as possible, the last vestiges of an unfortunate and ignominious page in this country's history." 213 Congress

20842 U.S.C. $\$ 2000 \mathrm{e}-2$.

209 Id. $\$ 2000 \mathrm{e}-(\mathrm{j})$.

210 Id.; see also Stcven D. Jamar, Accommodating Religion at Work: A Principled Approach to Title VII and Religious Freedom, 40 N.Y.L. SCH. L. REV. 719, 742 (1996) (noting that religion is the only trait singled out for this type of accommodation under Title VII).

211 See generally Tammi J. Lces, Notc, The Individual vs. the Employer: Who Should Be Held Liable Under Employment Discrimination Law?, 54 CASE W. RES. L. REV. 861 (2004) (explaining that federal law does not include individual liability, but that some state laws do).

212 See, e.g., Kolstad v. Am. Dental Ass'n, 527 U.S. 526, 545 (1999) ("The purposes underlying Title VII are similarly advanced where employers are encouraged to adopt antidiscrimination policies and to educate their personnel on Title VII's prohibitions."); Craig Robert Senn, Ending Discriminatory Damages, 64 ALA. L. REV. 187, 201 (2012) (stating that a purpose of heightened damages awards against employers is "to deter discriminatory employers by more severely punishing unlawful conduct").

213 Albcmarle Paper Co. v. Moody, 422 U.S. 405, 417-18 (1975) (quoting United States v. N.L. Indus., Inc., 479 F.2d 354, 379 (8th Cir. 1973)) (internal quotation marks omitted). 
has increased the penalties Title VII imposes on the company in order to increase the pressure on owners to root out impermissible discrimination because Title VII's original provisions provided insufficient deterrence. ${ }^{214}$

\section{The Religious Organization and BFOQ Exceptions}

Within this broad protection of religious liberty for moneymaking employees, Title VII recognizes two limited exceptions in situations where the employee's right to earn money without facing religious discrimination comes into conflict with an employer's right to exercise religion in hiring decisions. First, Title VII's prohibition on religious discrimination does not apply at all to "a religious corporation, association, educational institution or society" if that organization seeks to hire and fire based on religion. ${ }^{215} \mathrm{Sec}-$ ond, even for employers who are not covered by this "religious corporation" exemption, Title VII provides that religious discrimination can be permissible if religion is a "bona fide occupational qualification," or ("BFOQ.") $)^{216}$

On its face, the text of the religious corporation exemption does not distinguish between nonprofit and for-profit employers. ${ }^{217}$ Thus, nothing statutorily precludes an exempted "religious corporation" from earning profits while practicing or preaching religion. Further, the BFOQ provision expressly states that it is designed to include "businesses," thereby suggesting that Congress viewed profit-making businesses as capable of engaging in at least some religious exercises. ${ }^{218}$ Thus from the face of the statute, it is clear that businesses are entitled under Title VII to exercise religion in at least one respect-namely, by having jobs for which particular religious beliefs constitute a BFOQ.

The government observes that there are no reported cases in which forprofit companies successfully obtained the right to engage in religious discrimination under the exception. ${ }^{219}$ While this observation is correct, it is also incomplete. The government cites to one reported case in which a for-profit

214 See H.R. REP. No. 102-40, pt. 2, at 1-3, 24-25 (indicating that the punitive damages remedy added to Title VII by the Civil Rights Act of 1991 was needed to deter unlawful harassment and intentional discrimination in the workplace).

21542 U.S.C. $\S 2000 \mathrm{e}-1$ (a) (2006) ("This subchapter shall not apply to . . a religious corporation, association, educational institution, or society with respect to the employment of individuals of a particular religion to perform work connected with the carrying on by such corporation, association, cducational institution, or society of its activities.").

216 Id. $\S 2000 \mathrm{e}-2(\mathrm{e})$ ("Businesses ... with personnel qualified on the basis of religion ... [may hire] on the basis of [one's] religion . . . in those certain instances where religion . . . is a bona fide occupational qualification reasonably necessary to the normal operation of that particular business or enterprisc.").

217 Id. $\$ 2000 \mathrm{e}-1$.

$218 \mathrm{Id}$.

219 DOJ Hercules Motion to Dismiss, supra note 2, at 17. 
employer actually sought the Title VII religious employer exemption. ${ }^{220}$ In Equal Employment Opportunity Commission v. Townley Engineering \& Manufacturing Co., ${ }^{221}$ the Ninth Circuit determined that Townley was not a religious employer. ${ }^{222}$ Notably, although Townley was a for-profit employer, the court did not articulate a categorical rule. Rather, the court determined that the outcome of "each case must turn on its own facts" and "[a]11 significant religious and secular characteristics" should be considered. ${ }^{223}$ In other words, the court in Townley did not apply a categorical rule that profit-making businesses can never receive the Title VII exemption. Nor did it suggest, having failed to qualify for that one exemption, Townley was categorically incapable of religious exercise in other contexts. To the contrary, even while denying Townley's request for the exemption, the court did permit the company to assert Free Exercise rights to act according to the religious beliefs of its owner ${ }^{224}$ Townley thus suggests Free Exercise rights are not limited only to those entities permitted to hire and fire based on religion under Title VII, and that profit making is simply one factor among many that should be considered under Title VII.

In fact, there do not appear to be any courts in the Title VII area that approach the religious organization exception with anything like a blanket rule prohibiting profit makers' religious exercise. ${ }^{225}$ Two Justices referenced the issue of profit-making activities by religious organizations in Corp. of the Presiding Bishop of the Church of Jesus Christ of Latter-Day Saints $v$. $A m o s,{ }^{226}$ but those concurrences do not suggest a blanket rule and emphasize that the question was left open. The discussion of the issue in Amos in fact strongly suggests the Justices understood that religious institutions would

220 Bricf for the Appcllants at 17, Newland v. Sebclius, No. 12-1380 (10th Cir. Jan. 18, 2013) (citing Equal Emp't Opportunity Comm'n v. Townlcy Eng'g \& Mfg. Co., 859 F.2d 610, 617 (9th Cir. 1988)).

221859 F.2d 610 (9th Cir. 1988).

222 Id. at 619.

223 Id. at 618.

224 Id. at 619-20 \& n.15 ("Because Townley is merely the instrument through and by which Mr. and Mrs. Townlcy express their religious belicfs, it is unnecessary to address the abstract issuc whether a for profit corporation has rights under the Free Exercise Clause independent of those of its shareholders and officcrs. .. . [Thus] Townlcy has standing to assert Jake and Helen Townley's Free Exercise rights."); see also Stormans, Inc. v. Sclecky, 586 F.3d 1109, 1120 (9th Cir. 2009) ("[A] corporation has standing to assert the free excrcise right of its owners.").

225 See LcBoon v. Lancaster Jcwish Cmty. Ctr. Ass'n, 503 F.3d 217, 226-27 (3d Cir. 2007) (noting profit-making status as just one of nine factors to be considered becausc "whether an organization is 'religious' for purposes of the exemption cannot be based on its conformity to some preconceived notion of what a religious organization should do, but must be measured with reference to the particular religion identified by the organization. Thus not all factors will be relevant in all cases, and the weight given each factor may vary from case to case").

226483 U.S. 327 (1987). 
sometimes engage in profit-making activities, which suggests religious exercise and profit making are not fundamentally incompatible. ${ }^{227}$ Furthermore, the federal government's own EEOC Compliance Manual suggests profit making is one factor to consider but notes "[a]ll significant religious and secular characteristics" must be considered and that "no one factor is dispositive." 228

\section{For-Profit Businesses as Victims and Perpetrators of Religious Discrimination}

Rather than reaching out to help immigrant Muslim business owners like Abdi Aden, suppose the City of Minneapolis instead vowed that it would never conduct business with Afrik Grocery, Inc. or any other Muslim-owned business. Or imagine a state government does not like Hobby Lobby's advertisements inviting people to "know and love Jesus" and penalizes the company in some way. In those circumstances, it would be fairly easy to see the for-profit business as the victim of obvious religious discrimination. Generally speaking, American laws recognize that businesses can be victimized by such discrimination in the race context, and the government regularly adopts programs designed to eradicate such discrimination against businesses. ${ }^{229}$

227 Id. at 345 n.6 (Brennan, J., concurring). Justice Brennan's concurrence expressly notes that " [i] is also conceivable that some for-profit activities could have a religious character, so that religious discrimination with respect to these activitics would be justified in some cases." Id. Justice O'Connor cxplained that the decision left the Title VII/profit question open and expressed her uncertainty as to whether "activities conducted by religious organizations solcly as profit-making enterprises will be as likely to be directly involved in the religious mission of the organization." Id. at 349 (O'Connor, J., concurring). Justice O'Connor's uncertainty as to how profit-making activities of a religious nonprofit should be analyzed is telling. Just three years earlier, in Roberts v. U.S. Jaycees, Justice O'Connor wrote a concurrence suggesting that she believed the presence of substantial commercial activity would completely disqualify a group from treatment as an "cxpressive association" under the First Amendment's freedom of association. 468 U.S. 609, 635-36 (1984) (O'Connor, J., concurring). But see Colombo, supra note 24 (manuscript at 55-57) (noting that no other Justices joined in Justice O'Connor's Roberts opinion, and that her approach "betrays quite narrow and unimaginative thinking" about the range of possible commercial organizations). Justice O'Connor's unwillingness to assert a similar blanket rule in Amos suggests a possible softening from her position in Roberts.

228 EQual EMP'T OPPORTUNity COMM'N, EEOC COMPLIANCE MANuAl $\$ 12$ (Religious DISCRIMINATION), at 16-17 (2008) (alteration in original) (emphasis added) (internal quotation marks omitted), available at http:/www.ccoc.gov/policy/docs/rcligion.pdf.

229 See, e.g., About the 8(a) Business Development Program, SBA.gov, http://www.sba.gov/content/8a-business-development-0 (last visited Oct. 4, 2013) ("The 8 (a) program offers a broad scope of assistance to firms that are owned and controlled at least $51 \%$ by socially and economically disadvantaged individuals."); Socially Disadvantaged Eligibility, SBA.GOv, http:/www.sba.gov/content/socially-disadvantaged-eligibility (last visited Oct. 4, 2013) ("Under federal law, socially disadvantaged individuals are those who have been subjected to racial or ethnic prejudice or cultural bias . . ."); see also Exec. Order No. 11625, 36 C.F.R. 19967 (1971) (creating Minority Business Development Agency and explaining that " $\mathrm{t}] \mathrm{he}$ opportunity for full participation in our free enterprise system by socially and economically 
Although it seems less frequent, businesses discriminated against based on religion can similarly bring claims for unconstitutional discrimination. ${ }^{230}$ This suggests, both legally and socially, businesses are understood to be capable of having a religious identity if that identity is relevant to their status as a victim of discrimination. ${ }^{231}$

Likewise, there appears to be no difficulty in believing that a for-profit business can form and act upon subjective views about religion when those views are used to discriminate against an employee on religious grounds. Suppose that a large publicly traded corporation decided it would no longer hire Muslims or Catholics because it disagrees with their religion. In this case, it would be easy to see that the for-profit business reached a subjective belief about religion and acted on that belief in a way the law deems impermissible. Indeed, courts have no trouble accepting that for-profit businesses can form and act on subjective beliefs about religion in these contexts. ${ }^{232}$

Thus, discrimination law recognizes that a for-profit business can have a religious identity when it is discriminated against, and can form and act on beliefs about religion when it is found guilty of religious discrimination. Viewed in combination with Title VII's broad protection of the right to earn money without undue religious burdens, and its express inclusion of "businesses" within the religious BFOQ provision, religious discrimination law seems to support the notion that there is no fundamental incompatibility between profit making and religious exercise. The only place a for-profit/nonprofit distinction appears to have any weight is in courts' analysis of Title VII's religious organization exemption. But even there, all courts to address

disadvantaged persons is essential if we are to obtain social and economic justice for such persons and improve the functioning of our national cconomy"); cf. Atheist Marketplace, 4 ATHEISTS, http:/www.4atheists.com/atheist-market.html (last visited Oct. 4, 2013) (providing support for "the atheist community and atheist owned businesses" and urging readers to "please give these folks your support by simply doing business with them rather than theist firms").

230 See, e.g., Shcrwin Manor Nursing Ctr., Inc. v. McAuliffe, 37 F.3d 1216, 1221 (7th Cir. 1994) ("Sherwin presents a cognizable equal protection claim since it alleges that it was subjected to differential treatment by the state surveyors based upon the survcyors' anti-Semitic animus."); see also The Amber Pyramid, Inc. v. Buffington Harbor Riverboats, L.L.C., 129 F. App'x. 292, 295 (7th Cir. 2005) (holding that "[a] minority-owned corporation, like Amber Pyramid, assumes an 'imputed racial identity' from its sharcholders" (quoting Thinket Ink Info. Res., Inc. v. Sun Microsystems, Inc., 368 F.3d 1053, 1059 (9th Cir. 2004))).

231 The recognition that a business may be targeted based on the religious beliefs of its owners is, sadly, one with a long history. For example, in the Kristallnacht attacks of 1938, Nazis not only attacked Jewish homes and synagogues but also destroyed thousands of Jewish-owned businesses. See Louis L. Snyder, Kristallnacht, in 1 THE ENCYCLOPEDIA OF THE THIRD REICH 515 (Christian Zetner \& Friedmann Bedürftig eds., MacMillan Publ'g Co. 1991) (1985). The attackers obviously expected that attacking a busincss would put pressure on its owners.

232 See, e.g., Fischer v. Forestwood Co., 525 F.3d 972, 986-87 (10th Cir. 2008) (allowing a claim that a for-profit business corporation refused to hire plaintiff unless he would join a particular church); Ollis v. Hearthstonc Homes, Inc., 495 F.3d 570, 575-76 (8th Cir. 2007) (affirming a jury verdict for plaintiff in a religious discrimination case against a for-profit corporation). 
the question and the EEOC have rejected the idea that profit making makes an organization categorically ineligible for the exemption. And none suggests that ineligibility for that particular exemption renders a business incapable of all other forms of religious exercise.

These facts severely undermine any claim that a categorical forprofit/nonprofit distinction exists within Title VII or can be borrowed from Title VII and applied as a categorical bar to all other religious freedom claims by for-profit businesses and their owners.

\section{Tax Law}

The federal tax code provides a statutory basis for at least one categorical distinction between nonprofits and for-profits: eligibility for tax-exempt status under 26 U.S.C. $\S 501$ (c)(3). ${ }^{233}$ Even this distinction, however, does not suggest any type of categorical rule that religious exercise and profit making can never coexist. Moreover, the tax code's allowance of pass-through taxation for most for-profit business organizations undermines any claim that business owners are not receptive to pressures imposed on, or incentives offered to, their businesses.

\section{Tax Exempt Status and Profit Making}

Organizations are eligible for tax-exempt status under Section 501(c)(3) if they are organized for certain approved purposes ${ }^{234}$ and if "no part of the net earnings" of the organization "inures to the benefit of any private shareholder or individual." ${ }^{235}$ Many exempt organizations are religious in nature. ${ }^{236}$ The profit distinction is categorical in the sense that even an organization

\footnotetext{
233 I.R.C. § 501(c)(3) (2006 \& Supp. V 2012).

234 ld. (requiring that the organization be "organized and operated exclusively for religious, charitable, scientific, testing for public safety, literary, or educational purposes, or to foster national or international amatcur sports competition (but only if no part of its activitics involve the provision of athletic facilities or equipment), or for the prevention of cruelty to children or animals").

235 Id. Excmpt organizations under 501(c)(3) must also comply with certain limitations on their activities: "no substantial part of the activitics of which is carrying on propaganda, or otherwise attempting, to influence legislation ... and which does not participate in, or intervene in (including the publishing or distributing of statements), any political campaign on bchalf of (or in opposition to) any candidate for public office." Id.

236 Id. (noting that "religious" purposes are permissible). For example, the Little Sisters of the Poor run nursing homes for the elderly and poor and have excmpt status. See Our Home, LiTTLE SiSTERS OF THE POOR, http://www.littlesistersofthepoordelaware.org/our-home (last visited Oct. 4, 2013) ("As Little Sisters of the Poor we care for the elderly poor in the spirit of humble service we have received from our foundress, Saint Jeanne Jugan. We welcome the elderly as we would Jesus Christ himself and serve them with love and respect until God calls them home.").
} 
with approved purposes would not be exempt from taxation if it pays out earnings to owners. ${ }^{237}$

There are important ways, however, in which the profit distinction in this context does not suggest a categorical incompatibility between religious exercise and making money. For example, religious organizations are required to pay taxes if they earn what the IRS calls "unrelated business income."' ${ }^{238}$ According to the IRS: "Churches and religious organizations, like other tax-exempt organizations, may engage in income-producing activities unrelated to their tax-exempt purposes . . .."239 If the religious organization makes money from activities "unrelated" to its mission, it must pay taxes on that money. ${ }^{240}$

This tax treatment for religious nonprofits is clearly built on the assumption that there is nothing fundamentally incompatible between religion and making money. Indeed, the IRS even acknowledges that some income-producing activity may be so closely tied to a religious mission that it is not taxed at all (i.e., because it is "substantially related" to that mission). ${ }^{241}$ The tax code clearly suggests that religious exercise and taxable moneymaking are not mutually exclusive, or even unusual.

In a way, the same treatment applies to for-profit businesses themselves. Company profits that are distributed as profits are subject to ordinary corporate income taxes. However, if the company donates those profits to a church or other qualifying organization, the profits are no longer taxed. ${ }^{242}$ In fact, the tax code is somewhat biased in favor of corporate charitable giving compared to shareholder giving: money the corporation donates avoids corporate income taxes, while money the shareholder donates does not. ${ }^{243}$

237 I.R.C. $\$ 501(\mathrm{c})(3)$.

238 See id. $\S \S 511,513$; see also INTERNAL REVEnUE SERV., PUBL'N 598, TAX ON UNRELATED BUSINESS INCOME OF EXEMPT ORGANIZATIONS 2 (rcv. 2012), available at http://www.irs.gov/pub/irspdf/p598.pdf.

239 InTERnal Revenue Serv., Publ'N 1828, TAX Guide for Churches and Religious ORgANIZATIONS 16 (2009), [hercinaftcr IRS REligious ORganizATION TAX GuIDE], available at http://www.irs.gov/pub/irs-pdf/p1828.pdf.

240 Id. ("Many tax-excmpt organizations scll advertising in their publications or other forms of public communication. Gencrally, incomc from the salc of advertising is unrelated trade or business incomc."); see also I.R.C. $\S 512$.

241 I.R.C. § 513(a); see also United States v. Am. Bar Endowment, 477 U.S. 105, 109-10 (1986) (applying the "substantially related" test to detcrmine that income from group insurance products offered to members by a nonprofit bar association was taxable as unrelated business income); IRS RELIGIOUS ORGANIZATION TAX GUIDE, supra note 239, at 16-17.

242 See l.R.C. $\$ 170(a),(c)(2)(B)$ (making a deduction available for corporatc contributions to organizations "organized and operated exclusively for religious ... purposes"). This deduction is available so long as contributions do not excecd 10 percent of the company's taxable incomc. Id. $\$ 170(\mathrm{~b})(2)(\mathrm{A})$.

243 See Linda Suggin, Encouraging Corporate Charity, 26 VA. TAX REV. 125, 129 (2006) ("The tax law has long contained a bias in favor of charitable giving by corporations comparcd to charitable giving by individual sharcholders following distributions by corporations. In a system with a scparate corporate tax, a charitable contribution made by a corporation and deducted at the corporate level can generally be 
Thus the federal tax treatment of both nonprofit and for-profit organizations suggests the IRS understands that the same entity may both engage in religious exercises and earn profits.

\section{Pass-Through Taxation and Incentives for For-Profit Businesses and Business Owners}

Most businesses do not pay income tax directly but rather use what is known as "pass through" taxation, where taxes are paid by the owners rather than by the business entity itself. ${ }^{244}$ For example, the tax code provides that "[a] partnership as such shall not be subject to the income tax" but that "partners shall be liable for income tax only in their separate or individual capacities." 245 Limited liability companies may elect to pay their taxes as partnerships, ${ }^{246}$ and most do so. ${ }^{247}$

Most for-profit corporations file their tax returns as "S corporations."248 $\mathrm{S}$ corporations are corporations "that elect to pass corporate income, losses, deductions and credit through to their shareholders for federal tax purposes. " ${ }^{249}$ Like partners in a partnership, shareholders of S corporations report the flow-through of income and losses on their personal returns, rather than on corporate returns. Shareholders then pay taxes only once, at individual rates. $^{250}$ As of 2006, more than 66 percent of all corporate tax returns were for $\mathrm{S}$ corporations. ${ }^{251}$

This tax treatment of most for-profit businesses suggests the owners of businesses are not viewed as completely separate from their businesses. ${ }^{252}$

\footnotetext{
larger than a contribution that an individual shareholder can make out of a corporate distribution of the same available funds because the corporate tax burdens the funds distributed to shareholders, but not the funds contributed to charity.").

244 See Thompson v. United States, 87 Fcd. Cl. 728, 730 (2009) (“[M]ost LLCs elect partnership taxation.").

245 I.R.C. $\$ 701$ (2006).

246 Treas. Reg. $\$ 301.7701-3(b)$ (1)(i) (2012).

247 See Thompson, $87 \mathrm{Fed}$. Cl. at 730.

248 See id.

$249 S$ Corporations, IRS.Gov, http://www.irs.gov/Businesses/Small-Businesses-\&-Sclf-Employed/ S-Corporations (last updated Oct. 4, 2013); see also I.R.C. § 1361(b)(1)(A) (2006 \& Supp. V 2012) (limiting participation to corporations with one hundred or fewer shareholders).

$250 S$ Corporations, supra notc 249 ("This allows S corporations to avoid double taxation on the corporate income. $S$ corporations are responsible for tax on certain built-in gains and passive income.").

251 Heather Duffy Parisi, $S$ Corporation Returns, 2006, STAT. InCOME BULL., Summer 2009, at 92, 92, available at http://www.irs.gov/pub/irs-soi/09sumbul.pdf.

252 Susan Kalinka, Unresolved Issues Regarding Passthrough Entities, Community Property, and Federal Tax Law Create Headaches for Spouses in Louisiana, 69 LA. L. REv. 861, 861 (2009) ("Because a disregarded entity is disregarded as a separate entity from its owner, transactions between the disregarded entity and its owner are not taken into account and have no tax consequences. Thus, distributions from a disregarded entity to its owner are not subject to income tax.").
} 
Not surprisingly, policymakers across the political spectrum have recognized that the flow-through arrangement enables government treatment of forprofit businesses to incentivize the owners of these for-profit companies to take certain actions. ${ }^{253}$

Thus while the tax code suggests one way in which the for-profit/nonprofit distinction can be categorical (i.e., the availability of tax exempt status), it also makes clear that religion and profit making are not considered mutually exclusive. Nonprofit religious organizations actually are permitted to take part in unrelated moneymaking activities, so long as they pay taxes. Further, the tax code suggests there is not an absolute separation between most businesses and their owners for purposes of taxation. The tax code further suggests business owners are regularly expected to respond to pressures imposed upon, or incentives offered to, their businesses.

\section{E. Profit-Making Businesses and Constitutional Analysis}

The Supreme Court's 2010 decision in Citizens United v. Federal Election Commission ${ }^{254}$ highlighted the issue of whether corporations can exercise constitutional rights. The Citizens United decision confirms that corporations can exercise constitutional rights and, ${ }^{255}$ in the process, has prompted efforts to amend the Constitution to strip corporations of those rights. ${ }^{256}$

The question presented here, however, is not so much whether corporations have constitutional rights as a general matter, but whether nonprofit organizations have different and greater constitutional rights than for-profit

253 See, e.g., Karen Mills, Encouraging Small Business Hiring Through Tax Credits, WHITE HOUSE BLOG (Jan. 29, 2010, 2:32 PM), http://www.whitchouse.gov/blog/2010/01/29/cncouraging-small-business-hiring-through-tax-credits (noting proposed legislation to "provide a $\$ 5,000$ tax credit to over a million small businesses for every net new employee they hire, with other tax incentives for increasing wages"); Press Release, Nat'l Fed'n of Indep. Bus., NFIB Thanks U.S. Scnatc for Approving Bipartisan Stimulus Package (2008), http:/www.nfib.com/press-media/press-media-item?cmsid=44913 (National Federation of Independent Business praising a "stimulus package that includes tax incentives small business owners can use to invest in their companies and hire new employecs. ... One of the most important provisions included in the stimulus package is increasing the dollar amount for small business expensing limits from $\$ 125,000$ to $\$ 250,000$. This will allow small business owners to immediately write off business purchases and will help small business owners cxpand their businesses and hire new employecs." (internal quotation marks omitted)).

254558 U.S. $310(2010)$.

255 Id. at $342-43$.

256 See I Support the People's Rights Amendment, FREE SPEECH FOR PEOPLE, http://www.peoplesrightsamendment.org/ (last visited Oct. 5, 2013) (proposing a "Pcople's Rights Amendment"). The proposed amendment would declare that "rights protected by this Constitution" are "the rights of natural persons." I $d$. Furthermore, the amendment would provide a rule of construction that "[ $t]$ he words people, person, or citizen as used in this Constitution do not include corporations." Id. Notably, cven the proposed People's Rights Amendment docs not distinguish between for-profit and nonprofit corporations: it simply strips rights from all organizations, regardless of their profit structurc. Id. 
organizations. With the exception of some discussion of the matter in the Title VII context discussed above, the answer is clear: the profit distinction generally has no impact on constitutional analysis. In fact, the courts have repeatedly and expressly rejected the notion that any categorical distinction exists between nonprofits and for-profits in several areas of constitutional analysis.

\section{Commerce Clause}

Both the Supreme Court and lower courts have emphasized that an entity's status as for-profit or nonprofit has no bearing on whether its activities constitute "commerce" under the Commerce Clause. In Camps Newfound/Owatonna $v$. Town of Harrison, ${ }^{257}$ the Court explained that application of the Commerce Clause turns on the nature of the activities conducted, not on the for-profit or nonprofit nature of the entity engaged in the activities. ${ }^{258}$

The Camps Newfound/Owatonna case concerned two nonprofit church camps from Maine which were challenging a property tax exemption that favored institutions serving mostly Maine residents. ${ }^{259}$ The nonprofit camps, which served predominantly out-of-state campers, alleged the exemption was invalid under the dormant Commerce Clause. ${ }^{260}$ In finding the exemption invalid, the Court explained that the camps' nonprofit status did not control the Commerce Clause analysis. Rather, "the argument in favor of a categorical exemption for nonprofits is unpersuasive," 261 and there is "no reason why the nonprofit character of an enterprise should exclude it from the coverage ... of the Commerce Clause." ${ }^{262}$ Other courts have found the same. ${ }^{263}$

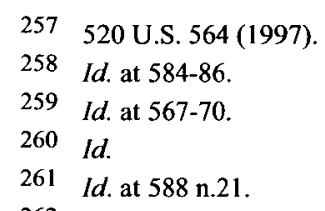

$262 \mathrm{Id}$. at 584 . The Court further explained that it had "similarly held that federal antitrust laws are applicable to the anticompetitive activities of nonprofit organizations" and that "the National Labor Rclations Act . . . applicd to the Associated Press' (A. P.'s) news gathering activities ... despite the fact that the A.P. 'does not sell news and does not operate for a profit."' Id. at 583-84 (quoting Associated Press v. NLRB, 30 I U.S. 103, 129 (1937)). In the labor context, some courts have included profits as part of their analysis for determining whether a religious school is a "church-operated school" within the meaning of NLRB v. Catholic Bishop of Chicago, 440 U.S. 490, 504 (1979). See, e.g., Univ. of Great Falls v. NLRB, 278 F.3d 1335, 1343-44 (D.C. Cir. 2002). Perhaps not surprisingly, however, there do not appear to be any reported cases in which courts actually analyze the case of a for-profit church-operated school sceking exclusion from the National Labor Relations Act based on Catholic Bishop, presumably because virtually all churches and church-operated schools are nonprofits.

263 See Edwards v. California, 314 U.S. 160, 172 n.1 (1941) ("It is immaterial whether or not the transportation is commercial in character."); Virginia Vermiculite, Ltd. v. W.R. Grace \& Co., 156 F.3d 535, 541 (4th Cir. 1998) (explaining "the dispositive inquiry is whether the transaction is commercial, not whether the entity engaging in the transaction is commercial"). 


\section{Free Speech Clause}

As Citizens United demonstrates, the Court takes a similar approach to First Amendment rights with respect to the Free Speech Clause. That is, the constitutional analysis does not turn on the identity of the speaker, whether that be an individual, a for-profit corporation, or a nonprofit corporation. Rather, the crux of the analysis is whether the speaker is engaged in protected speech.

The Court first articulated this principle as to profit-making corporate speakers in First National Bank of Boston v. Bellotti. ${ }^{264}$ There, the Court explained that " $[t]$ he proper question ... is not whether corporations 'have' First Amendment rights and, if so, whether they are coextensive with those of natural persons. Instead, the question must be whether [the challenged law] abridges expression that the First Amendment was meant to protect." ${ }^{265}$ The Court reiterated and expanded on this proposition in Citizens United, explaining that "political speech does not lose First Amendment protection 'simply because its source is a corporation." " ${ }_{266}$ Although the Court recognized corporations have "special advantages such as limited liability, perpetual life, and favorable treatment of the accumulation and distribution of assets," 267 it explained that "[i]t is rudimentary that the State cannot exact as the price of those special advantages the forfeiture of First Amendment rights." ${ }_{268}$ The Court also made clear that its ruling reached the First Amendment activities of corporations regardless of their status as for-profit or nonprofit entities, ${ }^{269}$ both of which of course enjoy the advantages of the corporate form.

Because the law at issue had an exception for media corporations, the Court considered whether the government could accord different speech rights to different corporations. ${ }^{270}$ The Court rejected such differentiation among corporate speakers as impermissible under the First Amendment:

Id., see also Simon \& Schuster, Inc. v. Members of N.Y. Statc Crime Victims Bd., 502 U.S. 105, 117 (1991) (rejecting the argument that an "entity" should have lesser First Amendment rights: "The government's power to impose content-based financial disincentives on speech surely docs not vary with the identity of the speaker').

266 Citizens United v. Fed. Elcction Comm'n, 558 U.S. 310,342 (quoting First Nat'l Bank of Boston v. Bellotti, 435 U.S. 765,784 (1978)).

267 Id. at 351 (quoting Austin v. Michigan Chamber of Commerce, 494 U.S. 652, 658-59 (1990)) (intcrnal quotation marks omittcd).

268 Id. (quoting Austin, 494 U.S. at 680 (Scalia, J., disscnting)) (intcrnal quotation marks omitted).

269 Id. at 365 ("No sufficient governmental interest justifics limits on the political speech of nonprofit or for-profit corporations."). The Court further explained that it overturned Austin v. Michigan Chamber of Commerce, 494 U.S. 652 (1990), becausc that decision allowed the government to "suppress[] the specch of manifold corporations, both for-profit and nonprofit," thereby "prevent[ing] their voices and viewpoints from rcaching the public." Id. at 354.

270 Id. at $350-52$. 
[T] he [media corporation] exemption results in a further, separate reason for finding this law invalid: Again by its own terms, the law exempts some corporations but covers others, even though both have the need or the motive to communicate their views. . . This differential treatment cannot be squared with the First Amendment. ${ }^{271}$

In the Free Speech context generally, the Court permits neither distinctions between corporate and non-corporate speakers, nor distinctions between different types of corporations.

\section{Commercial Speech Doctrine}

Nor do courts treat the for-profit/nonprofit distinction as significant when making determinations as to whether speech qualifies as "commercial speech" for First Amendment purposes. The Supreme Court has explained that what "defines commercial speech" is that it merely "proposes a commercial transaction"272 or "relate[s] solely to the economic interests of the speaker and its audience." ${ }^{273}$ Notably, this test turns on the content of the speech itself, rather than the nature or identity of the speaker. ${ }^{274}$

The Supreme Court has applied this test to determine whether speech is commercial or not, even when the speaker is a nonprofit. ${ }^{275}$ Lower courts applying this test have expressly recognized that whether speech is commercial does not depend on the speaker's status as a for-profit or a nonprofit entity. ${ }^{276}$ For example, in Aitken v. Communications Workers of America, ${ }^{277}$ a union claimed that its speech could not be commercial speech because it was organized as a nonprofit entity. The court rejected the claim because "status as a for-profit or non-profit entity cannot control whether [speech] is commercial speech in First Amendment terms." 278 Thus, as with speech generally and the Commerce Clause, the relevant constitutional analysis turns not on the for-

271 Id. at $352-53$.

272 Bd. of Trs. of the State Univ. of N.Y. v. Fox, 492 U.S. 469, 482 (1989)

273 Cent. Hudson Gas \& Elcc. Corp. v. Pub. Scrv. Comm'n of N.Y., 447 U.S. 557, 561 (1980)

274 See Rubin v. Coors Brewing Co., 514 U.S. 476, 494 (1995) (Stevens, J., concurring) ("[E]conomic motivation or impact alone cannot make speech less deserving of constitutional protection, or else all authors or artists who sell their works would be correspondingly disadvantaged."); Fox, 492 U.S. at 482 ("Some of our most valued forms of fully protected speech are uttered for a profit."); Adventure Comme'ns, Inc. v. Ky. Registry of Election Fin., 191 F.3d 429, 440-41 (4th Cir. 1999) ("In and of itself, profit motive on the speaker's part does not transform noncommercial speech into commercial speech.").

275 See, e.g., Vill. of Schaumburg v. Citizens for a Better Env't, 444 U.S. 620, 632 (1980) (performing commercial speech analysis to determine whether solicitation by a nonprofit corporation is commercial speech).

276 See, e.g., O'Brien v. Mayor \& City Council of Balt., 768 F. Supp. 2d 804, 813 n.9 (D. Md. 2011) aff'd in part, vacated in part en banc sub nom. Greater Balt. Ctr. for Pregnancy Concerns, Inc. v. Mayor \& City Council of Balt., 721 F.3d 264 (4th Cir. 2013) (vacating grant of summary judgment for procedural defects).

277496 F. Supp. 2d 653 (E.D. Va. 2007).

$278 I d$ at 663. 
profit or nonprofit nature of the actor, but on the nature of the activity in question.

\section{Establishment Clause}

Although the Court has never discussed the issue directly, it is clear that both for-profit and nonprofit entities can invoke the Establishment Clause of the First Amendment. For example, last Term the unanimous Court found that the Establishment Clause provides a "ministerial exception" for Hosanna-Tabor Lutheran Church and School, a nonprofit corporation. ${ }^{279}$

Other cases demonstrate that the Court does not limit its Establishment Clause jurisprudence to nonprofits. In fact, many of the Court's paradigmatic Establishment Clause cases involved for-profit businesses as plaintiffs, including Larkin v. Grendel's Den, Inc. ${ }^{280}$ Estate of Thornton v. Caldor, Inc., ${ }^{281}$ and Texas Monthly, Inc. v. Bullock. ${ }^{282}$ The for-profit/nonprofit distinction does not operate to bar for-profit businesses from asserting rights under the Establishment Clause.

As with the Commerce Clause, Free Speech Clause, and commercial speech doctrine, the Establishment Clause treatment of profit-making businesses confirms that the profit distinction does not drive constitutional analysis. Courts repeatedly reject the notion that any categorical rules about forprofits and nonprofits should be applied to control constitutional analysis. Instead of relying on the profit distinction, courts focus on the nature of the activity at issue, which governs the availability of constitutional rights. Thus, any argument to invest the profit distinction with determinative force in the religious liberty context would need to explain why a distinction that apparently carries no weight in other parts of the First Amendment - even elsewhere within the Religion Clause - should be viewed as categorical and dispositive where religious exercise rights are concerned.

279 See Hosanna-Tabor Evangelical Lutheran Church \& Sch. v. Equal Emp't Opportunity Comm'n, 132 S. Ct. 694, 703 (2012) ("The Establishment Clausc prevents the Government from appointing ministers ...."). As explained by the Sixth Circuit, Hosanna-Tabor is "an ecclesiastical corporation affiliated with the Lutheran Church-Missouri Synod." Equal Emp't Opportunity Comm'n v. Hosanna-Tabor Evangelical Lutheran Church \& Sch., 597 F.3d 769, 772 (6th Cir. 2010), rev'd, 132 S. Ct. 694 (2012).

280459 U.S. 116,117 (1982) (holding that the state may not delegate power over liquor licenses to churches).

281472 U.S. 703, $710-11$ (1985) (holding that the state may not grant Sabbath observers an absolute and unqualificd right not to work on their Sabbath).

282489 U.S. 1, 14 (1989) (holding that the statc may not grant an cntangling sales tax cxemption for religious periodicals). 


\section{ThE PROFIT DisTINCTION AND THE HHS MANDATE}

The federal government's recent arguments in the HHS Mandate cases provide the most prominent and comprehensive articulation of the argument against religious liberty for profit makers. In light of the information set forth in Parts I and II above, this portion of the Article will examine the government's argument that for-profit businesses "do not engage in the exercise of religion" and that the owner of a for-profit businesses can never experience a substantial burden on his religion when the government punishes his business.

\section{A. The Government's Argument Against Religious Liberty for Profit Makers in the HHS Mandate Context}

\section{The HHS Contraceptive Mandate}

The government's argument regarding the relationship between profits and religious liberty has been made in the preliminary stages of more than two dozen cases concerning what is popularly called the "HHS Mandate." 283 The HHS Mandate refers to a regulatory requirement issued under the Patient Protection and Affordable Care Act (the "ACA") ${ }^{284}$ The ACA requires that all "group health plan[s]" cover "preventive care and screenings" for women without cost sharing. ${ }^{285}$ HHS, the Department of Labor, and the Internal Revenue Service have adopted guidelines defining "preventive care" to include "[a]ll [FDA]-approved contraceptive methods, sterilization procedures, and patient education and counseling for all women with reproductive capacity." 286

283 "HHS" stands for the U.S. Department of Health and Human Scrvices, the agency that issucd the administrative rule.

284 Paticnt Protection and Affordable Care Act, Pub. L. No. $111-148,124$ Stat. 119 (2010).

28542 U.S.C \$ 300gg-13(a)(4) (2006 \& Supp. V 2012).

286 Women's Preventive Guidelines, HEALTH RES. \& SERVS. ADMIN., http://www.hrsa.gov/womensguidelines/ (last visited Oct. 5, 2013). FDA-approved contraceptives include the drugs levonorgestrel (commonly known as Plan B or the "moming-after pill") and ulipristal acetate (commonly known as Ella or the "week-after pill"), both of which can prevent implantation of a fertilized egg in the womb, thereby inducing an early-term abortion. Birth Control: Medicines to Help You, U.S. FoOD \& DRUG ADMIN., http://www.fda.gov/ForConsumers/ByAudience/ForWomen/FrecPublications/ucm313215.htm (last visited Oct. 5, 2013) (describing various FDA-approved contraccptives, including the emergency contraceptives Plan B and Ella). The Mandatc also includes copper intrauterine devices, or IUDs, which are widely acknowledged to interfere with implantation. See Pam Belluck, Abortion Qualms on Morning-After Pill May Be Unfounded, N.Y. TIMES (June 5, 2012), http:/www.nytimes.com $/ 2012 / 06 / 06 /$ hcalth/rescarch/morning-after-pills-dont-block-implantation-science-suggests.html (noting scientific arguments that emergency contraceptive drugs may not interfere with conception, but acknowledging that copper IUDs “can work to prevent pregnancy after an egg has been fertilized"). 
Under the ACA, employers with more than fifty employees must provide insurance coverage for these products and services. ${ }^{287}$ Failure to include this coverage triggers an assessment of $\$ 100$ per "affected individual" per day. ${ }^{288}$ Moreover, plan participants and beneficiaries may sue if a plan fails to cover the mandated products or services. ${ }^{289}$ Dropping employee health coverage altogether would subject the plan provider to an annual penalty of $\$ 2,000$ per employee. ${ }^{290}$

\section{Exemptions and Accommodations For Nonprofits}

From the outset, the HHS Mandate raised religious liberty concerns. ${ }^{291}$ Certain employers objected to the Mandate, claiming their religion precluded them from offering the required insurance coverage. ${ }^{292}$ In an attempt to address these concerns, the government has created two categories of religious objectors who will receive some protection. First, certain "nonprofit organization[s]," as described in the Internal Revenue Code, are deemed to be "religious employers" and therefore entirely exempt from the Mandate. ${ }^{293}$ This classification is limited to entities treated as churches or religious orders for tax purposes. ${ }^{294}$

Second, the government plans to offer other religious nonprofits an "accommodation" by which the coverage will not be mentioned in their insurance policies, but their insurer will directly provide it to their employees as a

288 I.R.C. $\$ 4980$ D(b) (2006 \& Supp. V 2012). See also Penalties for Employers Not Offering Affordable Coverage Under the Affordable Care Act, HENRY J. KAISER FAMILY FOUND., http://kaiscrfamilyfoundation.files.wordpress.com/2012/01/cmployer-penalty-flowchart-v3-071513.pdf (last updated July 15, 2013).

28929 U.S.C. $\$ \S 1132(a)(1)(B), 1185 d(a)(1)(2006)$.

290 I.R.C. $\$ \S 4980 \mathrm{H}(\mathrm{a}),(\mathrm{c})(1)$.

291 See, e.g., President Barack Obama, Remarks on Preventive Care (Fcb. 10, 2012) (noting that "the principle of religious liberty, an inalienable right that is enshrined in our Constitution" was at stake, and emphasizing it as a right he cherishes both "[a]s a citizen and as a Christian"), available at http://www.whitehousc.gov/the-press-office/2012/02/10/remarks-president-preventivc-carc.

292 See Group Health Plans and Health Insurance Issuers Relating to Coverage of Preventative Services Under the Patient Protection and Affordable Carc Act, 77 Fed. Reg. 8725, 8726 (Fcb. 15, 2012) (to be codificd at 45 C.F.R. pt. 147).

293 See I.R.C. $\$ \S 6033$ (a)(3)(A)(i), (iii) (2006) (excmpting "churches, their integrated auxiliarics, and conventions or associations of churches [and] the exclusively religious activities of any religious order"); 45 C.F.R. $\$ 147.130$ (a)(1)(iv)(B) (2012).

294 On February 6, 2013, the government issued a notice of proposed rulemaking that would eliminate prior requirements that a "religious employer" focus exclusively on indoctrination in the faith and hire and serve primarily members of that faith. Coverage of Certain Preventive Services Under the Affordable Care Act, $78 \mathrm{Fcd}$. Reg. 8456, 8461 (Feb. 6, 2013) (to be codified at 45 C.F.R. pts. 147, 148 \& 156). The government explained that climinating these requirements "would not cxpand the universe of employer plans that would qualify for the exemption beyond that which was intended in the 2012 final rulcs." Id. This formulation issucd as a final rulc on June 28,2013 . See 45 C.F.R. $\$ 147.130$. 
result of the issuance of the policy. ${ }^{295}$ Mechanically, the coverage would actually be part of a separate policy that the employer's insurer issues to the employee as an automatic consequence of the employer providing non-compliant health insurance. ${ }^{296}$ The stated goal of this approach is to "protect eligible organizations from having to contract, arrange, pay, or refer for contraceptive coverage to which they object on religious grounds." 297

The government has emphasized that the exemption and accommodation described above are only available for nonprofit entities. The government explained that because "the exemption for religious organizations under Title VII of the Civil Rights Act of 1964" does not apply to for-profit organizations, it would be "appropriate" to accommodate nonprofit, but not forprofit, employers. ${ }^{298}$ In limiting the accommodation to nonprofit entities, the government expressly stated that the profit or nonprofit taxpaying status of an organization-rather than its particular corporate form-is the controlling factor. ${ }^{299}$ Whereas any for-profit business, no matter what form it takes, is compelled to comply with the Mandate, "an organization that is organized and operated as a nonprofit entity is not limited to any particular form of entity." 300 Thus, corporate form, sincerity of religious conviction, and any other conceivable consideration are completely eclipsed by a single factor: profits.

\section{The Government's Two-Part Argument Against Religious Liberty for Profit Makers}

Because for-profit entities are not eligible for either the religious employer exemption or the accommodation, more than two dozen for-profit businesses and their owners have filed federal lawsuits seeking exemptions from the Mandate. ${ }^{301}$ In defending these suits, the government has argued for-

298 Id. Consistent with the government's positions in court, the notice of proposed rulcmaking ("NPRM") appears to divide religious objectors into two types of organizations: "non-profit religious" organizations and "for-profit secular" organizations. $I d$. This is a shift even from the spring of 2012, when the same government entities publicly sought comments on "whether, as some religious stakcholders have suggested, for-profit religious employers with such objections should be considered as well." Certain Preventive Services Under the Affordable Care Act, 77 Fed. Reg. 16501, 16504 (Mar. 21, 2012) (to be codificd at 45 C.F.R. pt. 147). The 2013 NPRM contains no mention of the existence of a "for-profit religious employer," as if such an entity does not exist.

299 Coverage of Certain Preventive Services Under the Affordable Care Act, 78 Fed. Reg. at 8462.

300 ld.

301 See, e.g., Conestoga Wood Specialties Corp. v. Sebelius, 917 F. Supp. 2 d 394 (E.D. Pa. 2013), aff'd, No. 13-1144, 2013 WL 3845365 (3d Cir. July 26, 2013); Annex Med., Inc. v. Sebelius, No. 122804(DSD/SER), 2013 WL 101927 (D. Minn. Jan. 8, 2013), appeal docketed, No. 13-1118 (8th Cir. Jan. 14, 2013); Newland v. Sebclius, 881 F. Supp. 2d 1287 (D. Colo. 2012), appeal docketed, No. 12-1380
} 
profit businesses and their owners are not eligible for religious freedom protection against the Mandate. ${ }^{302}$

The government's argument against religious liberty for profit makers has two separate components. First, the government argues a for-profit business corporation cannot itself exercise religion. ${ }^{303}$ And second, the government argues business owners are sufficiently separated from the business that they cannot allege a "substantial burden" on their religion sufficient to state a claim under federal religious freedom laws. ${ }^{304}$

\section{a. The Argument that a For-Profit Business Is Incapable of Engaging in Religious Exercises}

The government's argument against religious liberty for for-profit businesses is straightforward and simple: earning a profit is fundamentally incompatible with engaging in religious exercise. If an entity earns profits then, by definition, it cannot also engage in religious exercises. ${ }^{305}$ Profit making always crowds out religion.

The Hercules case provides a useful example. Hercules Industries, Inc. is a closely held Colorado corporation owned and operated by four Catholic siblings, the Newlands. ${ }^{306}$ Hercules manufactures and distributes HVAC systems. ${ }^{307}$ The Newlands and Hercules asserted that their religion forbids them

(10th Cir. Scpt. 26, 2012); Tyndale Housc Publishers, Inc. v. Scbclius, 904 F. Supp. 2d 106 (D.D.C. 2012), appeal dismissed, No. 13-5018, 2013 WL 2395168 (D.C. Cir. May 3, 2013); Grote Indus., LLC v. Sebelius, 914 F. Supp. 2d 943 (S.D. Ind. 2012), appeal docketed sub nom Grote v. Scbclius, No. 13-1077 (7th Cir. Jan. 9, 2013); Ycp v. U.S. Dep't of Health \& Human Servs., No. 12-CV-06756 (N.D. III. 2012), appeal docketed sub nom Triune Health Grp., Inc. v. Scbelius, No. 13-1478 (7th Cir. Mar. 5, 2013); Korte v. U.S. Dep't of Health \& Human Servs., 912 F. Supp. 2d 735 (S.D. Ill. 2012), injunction pending appeal granted by Korte v. Scbclius, No. 12-3841, 2013 WL 6757353 (Dcc. 28, 2013); Monaghan v. Scbelius, 916 F. Supp. 2d 802 (E.D. Mich. 2012), appeal docketed sub nom Domino's Farms Corp. v. Scbclius, No. 13-1654 (6th Cir. May 17, 2013); Legatus v. Sebclius, 901 F. Supp. 2d 980 (E.D. Mich. 2012), appeal docketed, Nos. 13-1092, -1093 (6th Cir. Jan. 24, 2013); Autocam Corp. v. Scbclius, 1:12-CV-1096, 2012 WL 6845677 (W.D. Mich. Dec. 24, 2012), aff'd, No. 12-2673, 2013 WL 5182544 (6th Cir. Sept. 17, 2013); O'Brien v. U.S. Dep't of Health \& Human Servs., 894 F. Supp. 2 d 1149 (E.D. Mo. 2012), appeal docketed, No. 12-3357 (8th Cir. Oct. 4, 2012); Sharpe Holdings, Inc. v. U.S. Dep't of Health \& Human Servs., No. 2:12-CV-92 (E.D. Mo. filed Dec. 20, 2012); Am. Pulverizer Co. v. U.S. Dep't of Health \& Human Scrvs., No. 12-CV-3459-CV-S-RED, 2012 WL 6951316 (W.D. Mo. Dec. 20, 2012), appeal docketed, No. 13-1395 (8th Cir. Feb. 25, 2013); Hobby Lobby Stores, Inc. v. Scbelius, 870 F. Supp. 2d 1278 (W.D. Okla. 2012), rev'd, No. 12-6294, 2013 WL 3216103 (10th Cir. Junc 27, 2013).

302 See Brief for the Appellecs at 7, Hobby Lobby, 870 F.Supp.2d 1278 (No. CIV-12-1000-HE).

303 Id. at 11.

304 Id. at 12

305 See DOJ Hercules Motion to Dismiss, supra notc 2, at 17.

306 See Newland, 881 F. Supp. 2d at 1292.

307 Id. "HVAC" is an acronym for heating, ventilation, and air-conditioning. 
from complying with the HHS Mandate..$^{308}$ The government responded that the company's goal of making money precluded Hercules from engaging in any exercise of religion. ${ }^{309}$ The government asserted that "there [was] nothing to indicate that Hercules Industries [was] anything other than a for-profit, secular employer." ${ }^{10}$ Under this one-size-fits-all approach, the government argued that profit-making status should be considered "conclusive." 311

The government's argument is completely contingent upon the presence or absence of profits, rather than by any particular characteristics of the business at issue. ${ }^{312}$ For example, the government advanced the same argument against Mardel Christian and Education, a chain of Christian bookstores, and Tyndale House Publishers, a Bible publisher directing 96.5 percent of profits to a Christian nonprofit foundation. ${ }^{313}$

The government derives this profit-based distinction from Title VII of the Civil Rights Act of 1964. ${ }^{314}$ As discussed above, Title VII prohibits employers from discriminating against employees and applicants on the basis of certain protected characteristics, including religion. ${ }^{315}$ However, the government argues that the exemption from Title VII for a "religious corporation,

308 Id. at 1292 (stating that the Newlands "seck to run Hercules in a manner that reflects their sincerely held religious beliefs" (internal quotation marks omitted)).

309 DOJ Hercules Motion to Dismiss, supra note 2, at 17-18. The government's intense focus on the issue of profits appears to be a relatively ncw strategy. Although in prior cases such as United States $v$. Lee the government did not argue that profit making was fundamentally inconsistent with religious exercise; indeed the word profit was not mentioned a single time. See Bricf for the United States, United States v. Lee, 455 U.S. 252 (1981) (No. 80-767), 1981 WL 389829. In contrast, the government's brief in the Hercules case mentions "profits" more than 30 times. DOJ Hercules Motion to Dismiss, supra note 2, passim. Nor has the government offered this categorical argument in other recent cases arguably touching on religious liberty for profit makers. See, e.g., Bricf for the Respondent, Tony \& Susan Alamo Found. v. Donovan, 571 U.S. 290 (1985) (No. 83-1935), 1985 WL 669832; Brief for the United States, Corp. of the Presiding Bishop of the Church of Jesus Christ of Latter-Day Saints v. Amos, 483 U.S. 327 (1987) (Nos. 86-179, 86-401), 1987 WL 864781.

310 DOJ Hercules Motion to Dismiss, supra note 2, at 17. This argument ignores that the Newlands are also plaintiffs. Cf. Order at 4, Korte v. Sebelius, No.12-3841 (7th Cir. Dec. 28, 2012), 2012 WL 6757353.

311 DOJ Hercules Motion to Dismiss, supra note 2, at 17

312 Id. ("By definition, a secular cmployer does not engage in any 'exercise of religion' .....).

313 See Hobby Lobby Stores, Inc. v. Sebelius, 870 F. Supp. 2d 1278, 1285 (W.D. Okla. 2012) (including Mardel, Inc., d/b/a Mardel Christian and Education); Tyndale House Publishers, Inc. v. Sebelius, 904 F. Supp. 2d 106, 111 (D.D.C. 2012).

314 See Hercules App. Br., supra note 154, at 14-15; see also Coverage of Certain Preventive Services Under the Affordable Care Act, 78 Fcd. Reg. 8456, 8462 (Feb. 6, 2013) (to be codified at 45 C.F.R. pts. $147,148 \& 156)$.

31542 U.S.C. § 2000e-2 (2006 \& Supp. V 2012) (providing that "[i]t shall be an unlawful employment practice for an employer ... to discriminate against any individual . . . because of such individual's ... religion"). 
association, educational institution, or society"-allowing such groups to engage in religious discrimination in hiring 316 - is part of the "special solicitude to the rights of religious organizations" under the Free Exercise Clause. ${ }^{317}$

The government argues only "religious organizations" that Title VII's exemption permits to hire and fire based on religion under Title VII may exercise religion under federal law. ${ }^{318}$ Because "[n]o court has ever found a for-profit corporation to be a religious organization" 319 for Title VII purposes, the government concludes that profit makers are also categorically barred from engaging in any other exercise of religion under religious freedom laws such as the Religious Freedom Restoration Act ("RFRA"). ${ }^{320}$ Instead, RFRA must be interpreted to include this distinction from Title VII. ${ }^{321}$

At least at the preliminary injunction stage of the HHS Mandate litigation, some courts have accepted the argument that for-profit businesses cannot exercise religion. ${ }^{322}$ For example, the Hobby Lobby trial court observed that businesses do not hold or exercise religious beliefs "separate and apart from ... their individual owners or employees." 323 The court found that corporate entities are unable to "pray, worship, observe sacraments or take other religiously-motivated actions" independent of their business owners. ${ }^{324}$ The court then concluded that the personal nature of religious exercise precluded a business from any form of legal religious protection. ${ }^{325}$

\section{b. The Argument that Owners of For-Profit Businesses Cannot Engage in Religious Exercises During Profit Making}

Plaintiffs in HHS Mandate cases generally include both the businesses and their owners. ${ }^{326}$ The owners typically assert that the Mandate constitutes

316 Id. $\S 2000 \mathrm{c}-1(\mathrm{a})$

317 Hosanna-Tabor Evangclical Lutheran Church \& Sch. v. Equal Emp't Opportunity Comm'n, 132

S. Ct. 694,706 (2012).

318 Hercules App. Br., supra note 154, at 16.

319 See Bricf for the Appcllecs at 11, Hobby Lobby Stores, Inc. v. Scbelius, 870 F. Supp. 2d 1278

(W.D. Okla. 2012) (No. 12-6294).

320 Id. at 12.

321 See Opposition to Plaintiffs' Emergency Motion for an Injunction Pending Appcal at 12, Annex Med., Inc. v. Scbelius, No. 13-1118 (8th Cir. Jan. 25, 2013) (arguing that "when Congress cnacted RFRA in 1993, it did so against the backdrop of the federal statutes that grant religious employers alone the prerogative to rely on religion in setting the terms and conditions of cmployment").

322 See, e.g., Conestoga Wood Specialties Corp. v. Scbelius, 917 F. Supp. 2d 394, 408 (E.D. Pa. 2013).

323 Hobby Lobby, 870 F. Supp. 2d at 1291.

$324 \mathrm{Id}$.

325 Id. (concluding that "[r]eligious cxercise is, by its nature, onc of those 'purcly personal' matters referenced in Belotti which is not the province of a general business corporation").

326 See, e.g., id. at 1293. 
a "substantial burden" under RFRA and the Free Exercise Clause. A substantial burden exists where the government imposes "substantial pressure" on an adherent to engage in conduct contrary to a sincerely held religious belief. ${ }^{327}$ The owners argue the Mandate creates substantial pressure on them by imposing severe financial penalties on their religious exercise of excluding certain services from insurance coverage. ${ }^{328}$ By forcing business owners to use their property (namely, the business) to include these services in insurance coverage, the owners argue the Mandate imposes substantial pressure on them to forfeit their religious objections and comply with the law. ${ }^{329}$

The government's response targets the plaintiffs' use of a for-profit company to earn their living. The government argues the owners voluntarily chose to conduct their business through a for-profit corporation, which is a separate legal entity. ${ }^{330}$ Accordingly, the owners have no right to complain about pressures imposed on them through that entity. ${ }^{331}$ The government essentially argues that because the plaintiffs enjoy limitations on liability and other benefits from the corporate form, they should not be permitted to "selectively contend--when it suits their interests - that they and the corporation are one and the same." ${ }_{332}$ The government further criticized the notion that a business owner can have a legitimate claim against government pressure imposed through a sanction on the business itself, arguing that a substantial burden may not be established "by invoking this type of trickle-down theory." ${ }^{333}$

\section{B. The Argument that Profit-Making Corporations and Their Owners Have Religious Liberty in the HHS Mandate Context}

The government's argument against religious liberty for profit makers purports to borrow the profit distinction from other areas of the law and apply

327 See, e.g., Abdulhaseeb v. Calbonc, 600 F.3d 1301, 1315 (10th Cir. 2010). This test is widely shared among the circuit courts applying RFRA. The Supreme Court has not yet needed to define "substantial burden" under RFRA, but has used similar language when describing actionable burdens under the Free Exercise Clausc. See, e.g., Sherbert v. Verner, 374 U.S. 398, 404 (1963) ("Here not only is it apparent that appellant's declared ineligibility for benefits derives solely from the practice of her religion, but the pressure upon her to forcgo that practice is unmistakable. The ruling forces her to choose between following the precepts of her religion and forfeiting benefits, on the one hand, and abandoning one of the precepts of her religion in order to accept work, on the other hand. Governmental imposition of such a choice puts the same kind of burden upon the free exercise of religion as would a fine imposed against appellant for her Saturday worship.").

328 See Hercules App. Br., supra note 154, at 28.

$329 I d$.

330 DOJ Hercules Motion to Dismiss, supra note 2, at 20-21.

331 Id. at 20.

332 Id. at $20-21$.

333 See Defendants' Opposition to Plaintiffs' Motion for Preliminary Injunction at 14, Tyndalc Housc Publishers, Inc. v. Sebelius, 904 F. Supp. 2d 106 (D.D.C. 2012) (No. 1:12-cv-1635). 
it to religious freedom claims. In light of the information presented in Parts I and II above, the government's argument fails for four principal reasons.

\section{For-Profit Businesses Exercise Religion}

First, there can be no serious question about whether for-profit corporations "exercise religion." As discussed in Part I.A, a religious exercise is simply an action or abstention based on a religious belief. As a matter of observable fact, for-profit corporations do sometimes act based on religious beliefs, as described in Part II.C. Closing for the Sabbath, taking out certain types of loans to comply with Islamic law, and urging others to "know Jesus Christ as Lord and Savior" are all obvious religious exercises. ${ }^{334}$

Comparison with the treatment of for-profit corporations in other areas confirms that such entities are regularly understood as being capable of acting on a wide range of subjective beliefs or intentions: ethical views, philosophical views, criminal intentions, anti-religious animus, etc. ${ }^{335} \mathrm{~A}$ shopping trip to Whole Foods or a lunch at Chipotle confirms that businesses frequently have ethical, moral, or philosophical commitments beyond mere profit maximizing. Our law recognizes that businesses can form and act on these types of subjective beliefs, and often it encourages such behavior. ${ }^{336}$

There is no basis in law or logic to say that corporations can form moral views about ethics, philosophy, and the environment, but not about religion. If NOOCH Vegan Market can choose not to sell pork because of an ethical commitment to not killing animals, it makes no sense to say Afrik Grocery, Inc. is incapable of making a similar choice based on religious commitments. And it makes even less sense to say that a corporation is capable of forming and acting on beliefs about religion when holding the corporation liable for religious discrimination, ${ }^{337}$ but not when the corporation engages in other, more positive actions based on beliefs about religion. Indeed, efforts to limit permissible corporate purposes to exclude religion have been rightly rejected

334 See supra Part I.B. In fact, the Affordable Care Act recognizes that a "facility" can have a conscientious objection to providing or referring for abortions, without requiring the facility be nonprofit. 42 U.S.C. § 18023(b)(4) (2006 \& Supp. IV 2011); see also 745 ILL. COMP. STAT. ANN. 70/10 (West 2010) (protecting any "person, association, or corporation" opcrating a "facility" from being forced to provide any healtheare services "which violate[] the healthcare facility's conscience," with no requirement that the facility be nonprofit); Morr-Fitz, Inc. v. Quinn, 976 N.E.2d 1160,1174 (III. App. Ct. 2012) (applying 745 ILL. COMP. STAT. ANN. 70/10 to protect a for-profit corporate pharmacy from regulation forcing it to dispense emergency contraceptives in violation of the pharmacy's conscience). The alternative financing program designed by Minncapolis further demonstrates that governments often recognize that some forprofit businesses are conducted according to religious requirements. See supra Part I.B.

335 See supra Part II.

336 See, e.g., supra Part II.B.

337 See supra Part II.B. 
as unconstitutional. ${ }^{338}$ Such discrimination against religious motivations would be a clear violation of Employment Division, Department of Human Resources of Oregon v. Smith ${ }^{339}$ In Smith, the Court said "[i]t would doubtless be unconstitutional" to target "acts or abstentions only when they are engaged in for religious reasons." 340 Thus the far better reading of these data points, and the only constitutional reading, is that for-profit businesses are quite capable of forming and acting upon religious beliefs and therefore engaging in religious exercise.

\section{The Free Exercise Clause and RFRA Protect Religious Exercise by Profit Makers}

Neither the Free Exercise Clause nor the Religious Freedom Restoration Act ("RFRA") refers to profit-making status. Rather, the Free Exercise Clause broadly establishes that "Congress shall make no law ... prohibiting the free exercise" of religion. There is no language to suggest limits as to whose free exercise is protected, or that it will be protected only in certain circumstances. ${ }^{341}$ Likewise, RFRA broadly restricts all government actions that "substantially burden a person's exercise of religion" with no indication that its protections are only available in nonprofit settings. ${ }^{342}$ Indeed, both RFRA and the Free Exercise Clause can be understood as limitations on government power, rather than mere grants of rights to particular parties.

Supreme Court cases decided under the Free Exercise Clause and RFRA suggest the Court has understood neither profit making nor the corporate form to expand the government's power to regulate religious exercise, or to interpose a categorical bar on religious liberty claims. For example, the Court has twice allowed commercial proprietors to assert religious claims against business regulation. In United States v. Lee, ${ }^{343}$ the Court allowed an Amish employer to assert religious objections to paying social security taxes in connection with his business. ${ }^{344}$ The Court found that Amish religious beliefs forbade both payment and receipt of social security benefits, and therefore "compulsory participation in the social security system interferes with their

338 See Falwell v. Miller, 203 F. Supp. 2d 624, 630 (W.D. Va. 2002) (invalidating a Virginia corporate statute prohibiting churches from incorporating). This makes sense. A law allowing a corporation to make decisions on other factors, but prohibiting it from making decisions based on religion, would obviously "impose special disabilities on the basis of religious views or religious status." Id. (quoting Emp't Div., Dep't of Human Res. of Or. v. Smith, 494 U.S. 872, 877 (1990)) (internal quotation marks omitted).

339494 U.S. 872 (1990).

340 Id. at $877-78$.

341 U.S. CONST, amend. I.

34242 U.S.C. \$ 2000bb(a)(3) (2006 \& Supp. V 2012).

343455 U.S. 252 (1982).

344 Id. at 257. 
free exercise rights. ${ }^{345}$ Likewise, in Braunfeld v. Brown, ${ }^{346}$ the Court allowed Jewish merchants to challenge a Sunday closing law because it "ma[d]e the practice of their religious beliefs more expensive." ${ }^{347}$ In each case, the Court found that the particular burdens at issue satisfied the compelling interest test. In neither did the Court suggest any bar on profit makers asserting religious liberty claims, or suggest that the particular arrangement of ownership under state law (which was presumably sole proprietorship) had any impact on the reach of the federal Free Exercise Clause. ${ }^{348}$

To the extent those cases left doubt about the relevance of the corporate form, the Court's decisions in Church of the Lukumi Babalu Aye, Inc. v. City of Hialeah ${ }^{349}$ and Gonzales v. O Centro Espirita Beneficente Uniao do Vege$\mathrm{tal}^{\mathrm{BSO}}$ appear to have resolved the doubt: the corporate form does not foreclose assertion of Free Exercise and RFRA rights. ${ }^{351}$ The $O$ Centro Espirita Court's implicit reading of RFRA's reference to "person" to include corporations is consistent with the federal statutory presumption that "person" usually includes corporations. ${ }^{352}$ As the Supreme Court explained in Monell v. Department of Social Services of the City of New York, ${ }^{353}$ this presumption is nothing new: "[B]y 1871, it was well understood that corporations should be treated as natural persons for virtually all purposes of constitutional and statutory analysis." 354

Furthermore, as Part II.E discussed, courts have routinely rejected arguments for categorical distinctions between nonprofit and for-profit entities for constitutional questions. That distinction carries no weight in Commerce Clause, Free Speech Clause, commercial speech, or Establishment Clause jurisprudence. There is no valid reason to invest the distinction with controlling weight only where the exercise of religion is concerned.

As a statutory matter, accepting the government's argument would require selectively interpreting the word "person" in RFRA to include corporations, but only some corporations (nonprofits) and not others (for-profits).

348 The Court's application of the Free Exercise Clause in Lee and Braunfeld is also consistent with cases such as Sherbert v. Verner, 374 U.S. 398 (1963), and Thomas v. Review Board of the Indiana Employment Security Division, 450 U.S. 707 (1981), both of which protect the Frec Exercise right to carn a living without facing government-imposed penalties on religious exercise.

349508 U.S. 520 (1993).

350 546 U.S. $418(2006)$.

351 See id. at 423 (deciding in favor of a New Mexcio corporation on its RFRA claim); Lukumi, 508 U.S. at 524 (awarding a Florida nonprofit corporation relief under the Free Exercise Clause).

352 See 1 U.S.C. $\S 1$ (2006) (stating that "person" ordinarily "include[s] corporations, companics, associations, firms, partnerships, societies, and joint stock companies, as well as individuals").

353436 U.S. $658(1978)$.

354 Id. at 687.
} 
Yet nothing in the statute's text suggests religious freedom rules are supposed to vary in this regard. To the contrary, the legislative history of RFRA strongly suggests one goal of RFRA was to impose a single, uniform standard for religious freedom claims across all contexts. ${ }^{355}$ In fact, when faced with a proposed amendment that would have lessened protection for prisoners, several representatives and senators argued that RFRA's uniform application of the compelling interest test must extend equally to everyone, even to people who are incarcerated. ${ }^{356}$ It is difficult to imagine that the same Congress that was concerned about ensuring uniform application of RFRA to prisoners was simultaneously (and silently) using the term "person" to selectively exclude some law-abiding businesses and their owners, simply because they earn profits.

\section{Title VII Law and the Tax Code Suggest Profit Makers Can Exercise Religion}

The government's attempt to use Title VII of the Civil Rights Act of 1964 to limit religious liberty for profit makers undermines the statute's principal function-protecting religious liberty for people earning a living. ${ }^{357}$ The statute provides no support for the government's argument that failure to qualify for Title VII's religious corporation exemption disqualifies an employer from all other exercises of religion. To the contrary, Title VII's religious exemption makes no reference to profit making at all. ${ }^{358}$ Courts interpreting that provision have not used profit making as a categorical bar but

355 See, e.g., Brief of Amici Curiae Sen. Orrin Hatch et al., Hobby Lobby Stores, Inc. v. Scbclius, 723 F.3d 1114 (10th Cir. 2013) (No. 12-6294), 2013 WL 773280, at *20 (noting RFRA's "one-rule-foreverybody principle reflected in RFRA's text and structure"); id. at *16-17 ("RFRA's statutory structure- a single rule with a single exception-reflects the principle that Government should apply the same protective standard to all exercises of religion, by all persons."); id. at * 18 ("Congress plainly wrote RFRA to include corporations ....").

356 Senators of both partics opposed what Senator Lieberman termed the "dramatic proposal" to create "two separate standards for the protection of religious frecdoms: protections afforded citizens out of jail and protections afforded incarcerated citizens." 139 CONG. REC. S14462 (daily ed. Oct. 27, 1993) (statement of Scn. Licberman); see also 139 CoNG. REC. S14465 (daily ed. Oct. 27, 1993) (statement of Sen. Hatch) (“[T]his amendment sets a dangcrous precedent for religious liberty. The real danger lies not so much in the exemption of prisoners, but in the choice we are making about exempting anyone from the principle of the free exercise of religion. Today we are asked only to exempt prisoners. Tomorrow, however, we will be asked to exempt others. . . How far we will venture is a legitimate unanswered question."); 139 CONG. REC. S14466 (daily ed. Oct. 27, 1993) (statement of Sen. Danforth) ("Congress should not codify group exceptions to fundamental freedoms."); 139 CONG. REC. S14467 (daily ed. Oct. 27, 1993) (statement of Sen. Kennedy) ("As we vote today to restore broad protection for religious freedom envisioned by the Framers of the Constitution, let us not deny this fundamental right to persons in prison.').

357 See supra Part III.A.3.

358 See 42 U.S.C. $\$ 2000 \mathrm{e}-1$ (2006 \& Supp. V). 
instead have emphasized that all aspects of an organization must be considered. ${ }^{359}$ Moreover, Title VII's "BFOQ" provision expressly includes "businesses," an inclusion that would be incoherent if Congress understood businesses as categorically incapable of religious exercise. ${ }^{360}$ This presumably explains why the EEOC's Compliance Manual recognizes the possibility of for-profit religious exercise. The EEOC's Compliance Manual views profit making as simply one factor among many, no one of which is dispositive..$^{361}$ Title VII simply contains no categorical prohibition on a profit maker's religious exercise.

The IRS takes a similar approach to the profit distinction in tax law: nonprofit churches and religious organizations are permitted to sometimes earn profits, as long as they pay their taxes. ${ }^{362}$ To take the most basic example, the IRS views ad sales on a church bulletin as an income-producing activity subject to taxation. Obviously the tax code recognizes the possibility that a tax-exempt religious nonprofit such as a church is capable of making money and paying taxes. If the tax code treated religion and profit making as fundamentally incompatible, these provisions would make no sense.

Furthermore, even if these other areas of the law suggested a categorically different treatment for nonprofit and for-profit entities, borrowing such distinctions from either Title VII or the Internal Revenue Code is particularly problematic in light of RFRA's express language stating that it trumps both pre-existing and future federal law. RFRA is a "super-statute," 363 which Congress expressly designed to control over other federal laws: "This chapter applies to all Federal law, and the implementation of that law, whether statutory or otherwise, and whether adopted before or after November 16, 1993." 364

Because other areas of federal statutory law do not treat religion and profit making as categorically incompatible, the profit distinction cannot create a categorical bar in the religious liberty context, particularly where federal law expressly requires RFRA to apply broadly.

359 See supra Part III.A.3.

360 See 42 U.S.C. $\$ 2000 \mathrm{e}-2(\mathrm{c})$.

361 See supra Part II.C.2.

362 See supra Part II.D.1.

363 “RFRA operates as a sweeping 'super-statute,' cutting across all other federal statutes (now and future, unless specifically exempted) and modifying their reach. ... [It] is thus a powerful current running through the entirc landscape of the U.S. Code." Michacl Stokes Paulsen, A RFRA Runs Through It: Religious Freedom and the U.S. Code, 56 MONT. L. REv. 249, 253-54 (1995).

36442 U.S.C. $\S 2000 \mathrm{bb}-3(\mathrm{a})$. 


\section{Owners of For-Profit Businesses Can Assert Religious Liberty Claims Under the Free Exercise Clause and RFRA}

Nor is there support for the claim that owners of a corporate business can never suffer a burden on their religion by virtue of penalties imposed on that business. Under RFRA, all that is necessary for a "substantial burden" is that the government impose "substantial pressure" on a person to change a religious exercise.

The government argues the benefit of limited liability means business owners cannot experience pressure from punishment of their businesses. As a matter of logic, however, it is difficult to see how the imposition of large fines on a business would not create substantial pressure on the owner of that business, even though the owner and the business are separate entities. ${ }^{365}$ Threatening to harm a person's business seems a very obvious way of imposing pressure on the person. This logic is confirmed by laws that impose punishments or offer incentives to corporations as ways of imposing positive or negative pressure on business owners. ${ }^{366}$

The separation argument is particularly inadequate in light of the tax treatment accorded to most corporations in the country as S corporations. ${ }^{367}$ If the government does not regard an owner as wholly separate from his closely held corporation for the important purpose of taxes, there is no reason to treat them as wholly separate when the same government is imposing tax penalties, which is how most of the HHS Mandate punishments are exacted. ${ }^{368}$

\section{CONCLUSION}

For the reasons set forth above, there is no basis for treating religion and profit making as mutually exclusive. Both for-profit businesses and their owners can assert religious freedom rights. Existing religious freedom law, observable facts about the behavior of businesses and business owners, and the general treatment of for-profit business organizations in a variety of circumstances all confirm that religious exercise by profit-making businesses and their owners are permitted and protected. The government has no greater power to prohibit free exercise in the profit-making context than it would to prohibit any other constitutional right-speech, establishment, abortion, or anything else-when practiced by people or organizations earning profits.

365 Indeed, the Court has previously recognized that far smaller financial penalties impose substantial burdens on religion. See, e.g., Wisconsin v. Yoder, 406 U.S. 205, 218 (1972) (finding that a five-dollar fine on religious practice created "not only severe, but inescapable" pressure).

366 See supra Parts II.C-D, III.A.

367 See supra Part II.D.

368 See, e.g., I.R.C. $\S \S 4980 \mathrm{D}, 4980 \mathrm{H}$ (2006 \& Supp. V) (penalties for failure to provide required insurance coverage). 
Denying religious liberty rights in the profit-making context requires treating religious exercise as a special and disfavored activity at every turn. Businesses would have to be deemed able to act on subjective motivations about ethics, the environment, and other non-financial beliefs. Yet, those businesses would be deemed unable to act on beliefs about religion. Business owners would have to be viewed as responsive to penalties imposed on their businesses through criminal law, tax policy, and discrimination law. But, businesses would be viewed as completely immune from pressure created by direct punishment of those same businesses for religious exercise. The Constitution would need to be read to ignore the profit distinction for every other type of analysis but to strictly embrace that same distinction as controlling in only the Free Exercise Clause. Title VII would need to be read not as broadly protective of the right to exercise religion while making money (which is surely its primary purpose) but as the source of a broad incapacity of all profit makers to exercise religion in any context whatsoever.

There is no principled or permissible reason to treat religious exercise in this specially disfavored manner. Doing so turns religious liberty law on its head, singling out religious exercise for special burdens rather than special protections. The government has no such power to discriminate against acts on the basis of the religious motivation behind those acts.

A categorical rule prohibiting religious exercise during profit making would impose a one-size-fits-all approach to religious liberty that is incompatible with the nation's religious diversity. The far better approach, and indeed the only approach permissible under our Constitution and religious freedom laws, is for the law to recognize that different people will engage in different religious exercises in a nearly limitless variety of contexts, including the profit-making context. Whether the law protects a particular act as religious exercise turns not on the type of tax return the actor files, but on whether the action is based on a sincere religious belief.

Of course, as a matter of religious belief, individuals and religious groups may still choose to adopt a strict interpretation of the theological statement that one "cannot serve both God and Money." But as a matter of religious freedom law, the government may not. 